\title{
Establishment of a large panel of patient-derived preclinical models of human renal cell carcinoma
}

\author{
Hervé Lang1, Claire Béraud ${ }^{2}$, Audrey Bethry², Sabrina Danilin ${ }^{3}$, Véronique Lindner ${ }^{4}$, \\ Catherine Coquard ${ }^{3}$, Sylvie Rothhut ${ }^{3}$, Thierry Massfelder ${ }^{3}$ \\ ${ }^{1}$ Department of Urology, Hôpitaux Universitaires de Strasbourg, Nouvel Hôpital Civil, Strasbourg, 67091 France \\ ${ }^{2}$ UROLEAD SAS, School of Medicine, Strasbourg, 67085 France \\ ${ }^{3}$ INSERM U1113, Section of Cell Signalisation and Communication in Kidney and Prostate Cancer, University of Strasbourg, \\ School of Medicine, Fédération de Médecine Translationnelle de Strasbourg (FMTS), Strasbourg, 67085 France \\ ${ }^{4}$ Department of Pathology, Hôpitaux Universitaires de Strasbourg, Hôpital de Strasbourg-Hautepierre, Strasbourg, 67200 \\ France
}

Correspondence to: Thierry Massfelder, email: massfeld@unistra.fr

Keywords: renal cell carcinoma, human tumors, patient-derived xenograft models

Abbreviations: CCC, clear cell renal cell carcinoma; PDX, patient-derived tumor xenograft; VHL, von Hippel-Lindau tumor suppressor gene

Received: September 08, 2015

Accepted: July 05, 2016

Published: July 18, 2016

\section{ABSTRACT}

The objective of the present work was to establish a large panel of preclinical models of human renal cell carcinoma (RCC) directly from patients, faithfully reproducing the biological features of the original tumor. RCC tissues (all stages/subtypes) were collected for $\mathbf{8}$ years from $\mathbf{3 3 6}$ patients undergoing surgery, xenografted subcutaneously in nude mice, and serially passaged into new mice up to 13 passages. Tissue samples from the primary tumor and tumors grown in mice through passages were analyzed for biological tissue stability by histopathology, mRNA profiling, von Hippel-Lindau gene sequencing, STR fingerprinting, growth characteristics and response to current therapies. Metastatic models were also established by orthotopic implantation and analyzed by imagery. We established a large panel of 30 RCC models (passage > 3, $\mathbf{8 . 9} \%$ success rate). High tumor take rate was associated with high stage and grade. Histopathologic, molecular and genetic characteristics were preserved between original tumors and case-matched xenografts. The models reproduced the sensitivity to targeted therapies observed in the clinic. Overall, these models constitute an invaluable tool for the clinical design of efficient therapies, the identification of predictive biomarkers and translational research.

\section{INTRODUCTION}

Renal cell carcinoma (RCC) is the most lethal urologic tumor and the sixth leading cause of cancer deaths in Western countries. Each year, around 340,000 patients are diagnosed with this malignancy resulting in approximately 150,000 deaths, and its incidence is increasing steadily [1]. RCC is resistant to radiotherapy and systemic therapies including the current targeted therapies. Although current therapies, including sunitinib, sorafenib and everolimus, have proven beneficial in treating RCC, complete response remains a rare event [2]. The lack of validated biomarkers restricts our ability to tailor specific drugs to patients and might be considered as the most important barrier for a better clinical outcome.

RCC tumors consist of several histological subtypes, including clear cell (CCC, $\sim 75 \%$ ), papillary $(\sim 12 \%)$, chromophobe $(\sim 4 \%)$, collecting duct $(\sim 1 \%)$ and unclassified $(\sim 4 \%)$ carcinomas [2]. Models of human cancer in mouse or rat are critical (i) for a better understanding of the tumor pathobiology, invasion and resistance, (ii) to define new therapeutic options, (iii) to identify predictive biomarkers guiding adequate therapy and (iv) to identify prognostic and diagnostic biomarkers. It is however essential that animal model mimics as closely as possible the heterogeneity of the original tumors to reach these goals. 
Hereditary RCC occurs in Eker rats that are heterozygous for an insertion mutation in the rat homologue of the tuberous sclerosis complex 2 ( $T s c 2$, encoding tuberin), a tumor suppressor gene that renders heterozygous mutants highly susceptible to renal carcinogens [3, 4]. This model, in which the incidence of RCC in gene carriers approaches $100 \%$ by 1 year of age, has been used to study the molecular pathways of renal tubular epithelial carcinogenesis, but despite its significance for studying some of the genetic alterations occurring during renal tumorigenesis, it represents mostly chromophobe RCC and benign oncocytoma arising from the collecting duct and not from the proximal tubule as for CCC [5]. There are no transgenic models of RCC despite the attempt of some investigators to develop such mice by interfering with the expression of von Hippel-Lindau (VHL) tumor suppressor proteins [6], that are part of the machinery leading to HIF factors degradation, HIF [7] or Pax2 transcription factors [8]. RCC models currently available are based on the subcutaneous (generally non-invasive model) or orthotopic (invasive model) implantation of human RCC cell lines into nude mice [9-11]. These models suffer from various limitations including that (i) they are clonal cell lines that do not recapitulate the heterogeneity of the tumors found in situ, (ii) the number of available and characterized cell lines is limited and (iii) cancer cells cultured in vitro are known to acquire genetic variability not found in the original tumors and to be sentitive to all therapeutic compounds [1214], a behaviour not found in the in vivo environment.

To date, the most accurate models are patientderived tumor xenografts (PDX) resulting from the implantation of viable cancer tissues into nude mice, as it has been shown for various cancer types, including bladder [15], breast [16], pancreatic [17], lung [18], ovarian [19], colon [20], liver [21] cancers and melanoma [22]. These models reflect the heterogeneity of the original tumors and allow tumor-stroma interactions found in tumors in situ that cannot be recapitulated by in vitro experiments. Few studies using a limited panel of patients show that such approaches are suitable to develop patient-derived RCC models in nude mice [23-34].

In the current study, we describe the development of a large panel of well-characterized patient-derived RCC models based on subcutaneous implantation of freshly harvested tumors. Our results show that these models reproduce the sensitivity to targeted therapies observed in the clinic and that they very closely mimic human RCC, providing valuable opportunities to increase our knowledge of kidney tumorigenesis.

\section{RESULTS}

\section{Tumor implantation and growth characteristics}

During the last 8 years, 336 RCC tumors were obtained directly from patients who underwent either partial or radical nephrectomy (Table 1). Eligibility criteria were based on preoperative imaging studies and included tumors of all subtypes and stages, multifocal, bilateral or, regional.

Most patients were males (59\%) and their age ranged between 32 to 86 years (Table 1). Over 90\% were renal cell carcinoma and 78\% were of the clear cell type (Table 1). About $50 \%$ of the RCC were of high grade and sarcomatoid elements were found in $13 \%$ of cases. Thirty tumor grafts were passaged at least three times (P3) in mice (take rate $8.9 \%$ ) and these are referred to as models RCCPDX1 to RCCPDX30 depending on the time of establishment (Table 2). The developing process is presented in Figure 1.

We noticed that tumor stage, high Fuhrman grade as well as sarcomatoid differentiation were associated with higher engraftment. We obtained a $4.0 \%$ success rate at pT1 stage (7 RCCPDX models from xenografting 174 tumors) vs. a $20 \%$ success rate at pT3 stage (RCCPDX models from xenografting 102 tumors). In our study, we chose to xenograft all RCC tumors operated at the New Hospital Civil of Strasbourg, in order to have a panel of RCCPDX models covering all stages. Thus there were no ineligibility criteria for the tumors we implanted. Concerning Fuhrman grade, for grade 1, the xenograft success rate was 0\% (O RCCPDX models from xenografting 20 tumors); for grade 2, the success rate was $2.8 \%$ (4 RCCPDX models from xenografting 142 tumors); for grade 3 , the success rate was $12.5 \%$ (12 RCCPDX models from xenografting 96 tumors) and from grade 4, the success rate was $36.1 \%$ (13 RCCPDX models from xenografting 36 tumors). Thus, for low grade $(1+2)$, the success rate was $2.5 \%$ (4 RCCPDX models from xenografting 162 tumors) and for high grade $(3+4)$, the success rate was $18.9 \%(25$ RCCPDX models from xenografting 132 tumors). For sarcomatoid differentiation, 13 PDX were developed from 44 tumors, i.e. $\sim 30 \%$ (Table 1). There were no other tumor parameters influencing this rate, among the ones studied. In addition, the average latency period for the first growth in mice was variable, ranging from 1 to 12 months. Again, there was no tumor parameter influencing this data. Tumor growth was assessed in some models and was dependent on the RCCPDX model but was quite similar from mouse to mouse (Figure 2) and from passage to passage (data not shown). All models were free of viruses and pathogens (data not shown).

\section{Histologic, molecular and genetic stability of the models}

A very important requirement for PDX models is that they should keep the histologic, molecular and genetic characteristics of the patient's tumor from which they derived to have preclinical and clinical relevance. We performed H\&E staining on all RCCPDX models at P0 (primary tumor) and at the different subsequent passages in mice, as indicated (Figure 3 and Table 3). 
Table 1: Patients, Tumor and PDX characteristics

\begin{tabular}{|c|c|c|c|}
\hline & & $\begin{array}{c}\text { Original Tumor } \\
\text { n (\%) }\end{array}$ & $\begin{array}{l}\text { PDX models } \\
\text { n }(\%)\end{array}$ \\
\hline \multirow[t]{2}{*}{ Age } & $<60(32-58 ; 50.4 \pm 2.7)$ & $131(39)$ & $10(33.3)$ \\
\hline & $\geq 60(60-86 ; 70.1 \pm 1.6)$ & $205(61)$ & $20(66.7)$ \\
\hline \multirow[t]{2}{*}{ Sex } & Female & $138(41)$ & $8(27)$ \\
\hline & Male & $198(59)$ & $22(73)$ \\
\hline \multirow[t]{7}{*}{ RCC subtype } & $\mathrm{CCC}$ & $262(78)$ & $24(80)$ \\
\hline & Papillary RCC & $26(7.7)$ & $1(3.3)$ \\
\hline & Oncocytoma & $21(6.3)$ & - \\
\hline & Chromophobe RCC & $18(5.4)$ & $1(3.3)$ \\
\hline & Composite RCC & $5(1.5)$ & $2(6.7)$ \\
\hline & Medullary RCC & $2(0.6)$ & $1(3.3)$ \\
\hline & Unclassified RCC & $2(0.6)$ & $1(3.3)$ \\
\hline \multirow[t]{11}{*}{ pT stage } & pT1 & $5(1.6)$ & - \\
\hline & pT1a & $109(35.5)$ & $1(3.3)$ \\
\hline & pT1b & $60(19.5)$ & $6(20)$ \\
\hline & pT2 & $14(4.5)$ & - \\
\hline & pT2a & $7(2.3)$ & - \\
\hline & pT2b & $2(0.7)$ & - \\
\hline & pT3 & $10(3.3)$ & $2(6.7)$ \\
\hline & pT3a & $42(13.7)$ & $5(16.7)$ \\
\hline & pT3b & $45(14.7)$ & $10(33.3)$ \\
\hline & pT3c & $3(1)$ & $3(10)$ \\
\hline & pT4 & $10(3.3)$ & $3(10)$ \\
\hline \multirow[t]{4}{*}{ Furhman grade } & 1 & $20(6.8)$ & - \\
\hline & 2 & $142(48.3)$ & $4(13.8)$ \\
\hline & 3 & $96(32.7)$ & $12(41.4)$ \\
\hline & 4 & $36(12.2)$ & $13(44.8)$ \\
\hline
\end{tabular}

Histopathology analysis of all models was performed by an experienced pathologist specialized in uropathology, and showed that RCCPDX models retained the histology features of the parental tumor, including cancer subtype, stage, cytological shape, and Fuhrman grade.

To determine whether serial xenografts keep molecular stability, we performed the analysis of the whole human transcriptome in a subset of RCCPDX models (RCCPDX13, 15, 16, 18 and 23) at P0 and at 3 to 5 subsequent passages in mice ( $\mathrm{P} 1$ to $\mathrm{P} 8$, as indicated) (Figure 4). On a total of 20313 genes spotted on the human cDNA arrays there were between $116(0.6 \%)$ and 399 $(2.0 \%)$ genes differentially expressed depending on the RCCPDX model (data not shown). No specific molecular features could be deduced from the analysis of these differentially expressed genes. Analysis of the combined data showed that 33 differentially expressed genes were common among all RCCPX models tested 32 were downregulated and 1 was up-regulated. However, no specific molecular features could be deduced from this restricted list (Table 4). Importantly, there was no change in gene expression among passages (Figure 4). The expression data files have been deposited in GEO, accession number GSE83820 (http://ncbi.nlm.nih.gov/geo/query/acc. cgi?acc $=$ GSE83820).

We further investigated whether genetic alterations were similar between the primary and subsequent grafted tumors through STR fingerprinting (Table 5) and VHL gene 
Table 2: RCCPDX characteristics

\begin{tabular}{|c|c|c|c|c|c|c|c|}
\hline $\begin{array}{l}\text { RCCPDX } \\
\text { ID }\end{array}$ & Gender & $\begin{array}{c}\text { Age at } \\
\text { diagnosis }\end{array}$ & $\begin{array}{c}\text { Year of first } \\
\text { engraftment in } \\
\text { mouse }\end{array}$ & RCC subtype & pTNM stage & $\begin{array}{c}\text { Fuhrman } \\
\text { grade }\end{array}$ & $\begin{array}{l}\text { Sarcomatoid } \\
\text { features }(\%)\end{array}$ \\
\hline RCCPDX1 & M & 69 & 2007 & $\mathrm{CCC}$ & pT3bN2 & 3 & \\
\hline RCCPDX2 & M & 86 & 2007 & $\mathrm{CCC}$ & $\mathrm{pT} 3 \mathrm{bNx}$ & 4 & $<1 \%$ \\
\hline RCCPDX3 & M & 70 & 2008 & $\mathrm{CCC}$ & pT3bN1 & 3 & $20 \%$ \\
\hline RCCPDX4 & $\mathrm{F}$ & 60 & 2008 & $\mathrm{CCC}$ & $\mathrm{pT} 1 \mathrm{bNx}$ & 2 & \\
\hline RCCPDX5 & M & 70 & 2008 & $\mathrm{CCC}$ & pT3bN0 & 3 & \\
\hline RCCPDX6 & M & 58 & 2008 & Composite RCC & $\mathrm{pT} 3 \mathrm{cN} 2$ & 3 & $20 \%$ \\
\hline RCCPDX7 & M & 61 & 2008 & $\mathrm{CCC}$ & pT3bN0 & 3 & \\
\hline RCCPDX8 & M & 75 & 2009 & $\mathrm{CCC}$ & pT1bNx & 4 & $15 \%$ \\
\hline RCCPDX9 & M & 60 & 2009 & $\mathrm{CCC}$ & pT1bN0M1 & 4 & $30 \%$ \\
\hline RCCPDX10 & $\mathrm{F}$ & 53 & 2009 & Chromophobe RCC & pT4N0 & 4 & $80 \%$ \\
\hline RCCPDX11 & $\mathrm{F}$ & 39 & 2009 & $\mathrm{CCC}$ & pT3bN1 & 4 & $50 \%$ \\
\hline RCCPDX12 & $\mathrm{F}$ & 65 & 2009 & $\mathrm{CCC}$ & $\mathrm{pT} 1 \mathrm{bNx}$ & 2 & \\
\hline RCCPDX13 & M & 57 & 2009 & $\mathrm{CCC}$ & pT3b & 4 & \\
\hline RCCPDX14 & M & 74 & 2010 & $\mathrm{CCC}$ & pT3aNxMx & 3 & \\
\hline RCCPDX15 & M & 62 & 2010 & $\mathrm{CCC}$ & pT3cN2Mx & 4 & $15 \%$ \\
\hline RCCPDX16 & M & 74 & 2010 & $\mathrm{CCC}$ & pT3bN0Mx & 2 & \\
\hline RCCPDX17 & M & 80 & 2010 & $\mathrm{CCC}$ & $\mathrm{pT} 1 \mathrm{~b}$ & 2 & \\
\hline RCCPDX18 & F & 76 & 2010 & $\mathrm{CCC}$ & pT4N2 & 4 & $20 \%$ \\
\hline RCCPDX19 & M & 57 & 2011 & $\mathrm{CCC}$ & pT3bM1 & 4 & $20 \%$ \\
\hline RCCPDX20 & M & 51 & 2011 & Composite RCC & pT3bN1 & 4 & $5 \%$ \\
\hline RCCPDX21 & M & 49 & 2011 & $\mathrm{CCC}$ & pT3aN2M1 & 3 & $40 \%$ \\
\hline RCCPDX22 & M & 72 & 2011 & $\mathrm{CCC}$ & pT3aN2 & 3 & \\
\hline RCCPDX23 & M & 66 & 2011 & $\mathrm{CCC}$ & pT1a & 3 & \\
\hline RCCPDX24 & $\mathrm{F}$ & 75 & 2011 & Unclassified RCC & pT4Nx & 4 & $100 \%$ \\
\hline RCCPDX25 & $\mathrm{F}$ & 69 & 2012 & $\mathrm{CCC}$ & $\mathrm{pT} 3 \mathrm{cN} 0$ & 3 & \\
\hline RCCPDX26 & M & 52 & 2012 & $\mathrm{CCC}$ & pT3N0 & 3 & \\
\hline RCCPDX27 & M & 32 & 2012 & Medullary RCC & pT3 & l & \\
\hline RCCPDX28 & $\mathrm{F}$ & 64 & 2012 & $\mathrm{CCC}$ & $\mathrm{pT} 1 \mathrm{bNx}$ & 4 & \\
\hline RCCPDX29 & M & 74 & 2013 & Papillary RCC & pT3aN2 & 3 & \\
\hline RCCPDX30 & M & 56 & 2014 & $\mathrm{CCC}$ & pT3aNx & 4 & \\
\hline
\end{tabular}

mutations analysis (Table 6). STR analysis was performed on DNA from all RCCPDX models at the indicated passages. VHL analysis was performed on DNA from the same RCCPDX models as specified above and at the indicated passages. STR analysis confirmed that xenografts came from the original patients' tumors, thus showing that there was no contamination within RCC tumors. We observed high rate of Y chromosome loss during passages compared to the original tumor $\mathrm{P} 0$, as reported in the literature [35]. Indeed, there were 22 RCCPDX models from patients with $\mathrm{X}$ and $\mathrm{Y}$ chromosomes present at $\mathrm{P} 0$, among which, in 11 cases, there was a loss of the $\mathrm{Y}$ chromosome during subsequent passages, i.e in half of the cases. There were some minor changes in the STR profile for some models, as expected when dealing with PDXs and as previously reported by other investigators, in RCC 
models and models derived from other tumor types (Table $5)[24,25,28]$. Through direct sequencing of the 3 exons of the VHL gene, we detected mutations in 4 out of the 5 cases analyzed (80\%). For all cases, identical mutations were observed between the primary tumor P0 and the subsequent passages (Table 6).

\section{Responses to therapeutic compounds}

To assess whether RCCPDX models would reproduce the sensitivity to targeted therapies observed in the clinic, we tested the response to reference compounds in vivo.

We measured the response of $7 \mathrm{RCC}$ models to sunitinib, sorafenib and everolimus. We observed a great variation in the profile of responses to the different therapies depending on the model considered (Figure 5 and Table 7). Tumors responded to sunitinib, the current first line therapy in 2 models, i.e $28 \%$ of cases, recapitulating what is observed in clinic. However, it is important to note that some tumors tested resistant to sunitinib were sensitive to either sorafenib or everolimus and one in the panel tested was sensitive to all three therapies. No complete response was observed in the course of these studies as it is the case in the large majority of clinical situations. It should be stressed that the original patients received treatment post- surgery in only rare cases in our RCCPDX models panel. For RCCPDX15 the corresponding patients was treated with nexavar, but he had severe side effects, and then temsirolimus; for RCCPDX18, the corresponding patient died before receiving sunitinib, and for RCCPDX 6 , the corresponding patient received palliative care. The consequence of that was that there was only one RCCPDX model, RCCPDX10, that was derived from a patient who received sunitinib as first line therapy. The patient did not respond to the treatment and the same was observed in the RCCPDX model derived from his tumor (Table 7). Similarly, we observed sensitivity to sunitinib in a model derived from a node metastasis, exactly as the response of the patient (data not shown). With such a low number of cases, we could not assess the predictability value of the RCCPDX models generated.

\section{Metastasis analysis}

Primary tumors and metastasis were monitored during one month following implantation (Figure 6). No signal was observable before IR780 injection. In the model shown, RCCPDX20, primary tumor and lung metastasis were observed 3 weeks post-implantation; 4 weeks post-implantation, we also observed brain metastasis. These data indicate that during passages in mice, tumor tissues conserved their ability to invade, and at classical metastatic localizations.

\section{DISCUSSION}

We xenografted in nude mice 336 RCC tumors of all subtypes and stages obtained from patients at the time of surgery from which we developed 30 models (P3 and above). It took up to 24 months to develop such model. We demonstrated that these models grow after both subcutaneous and orthotopic implantation, and are stable at the (i) histologic, (ii) genetic and (iii) molecular levels.

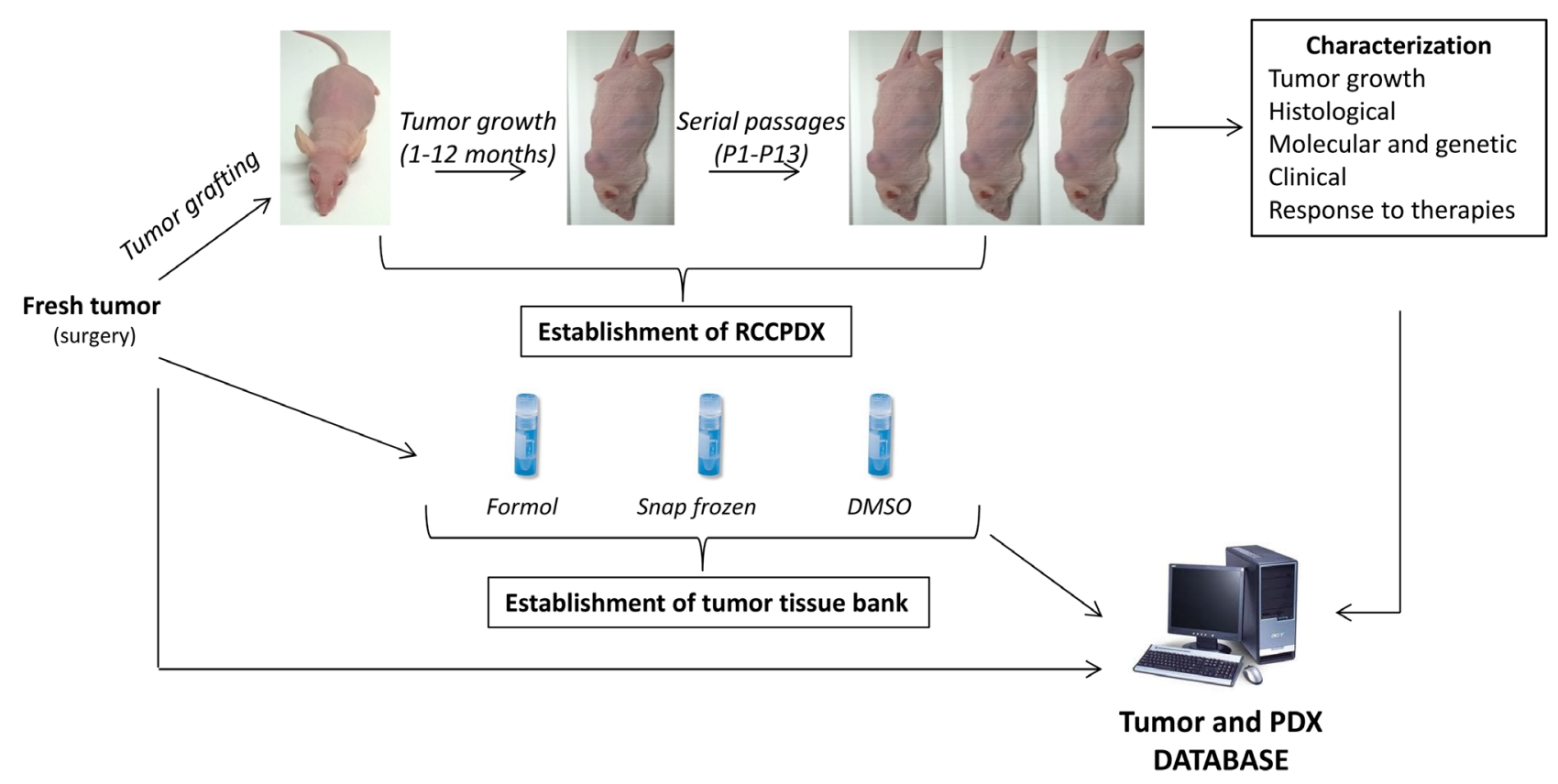

Figure 1: Schematization of the RCCPDX development processes. They include the establishment of the PDXs, their characterization at the different indicated levels and the establishment of tumor tissue bank, all data forming the tumor and PDX database. 

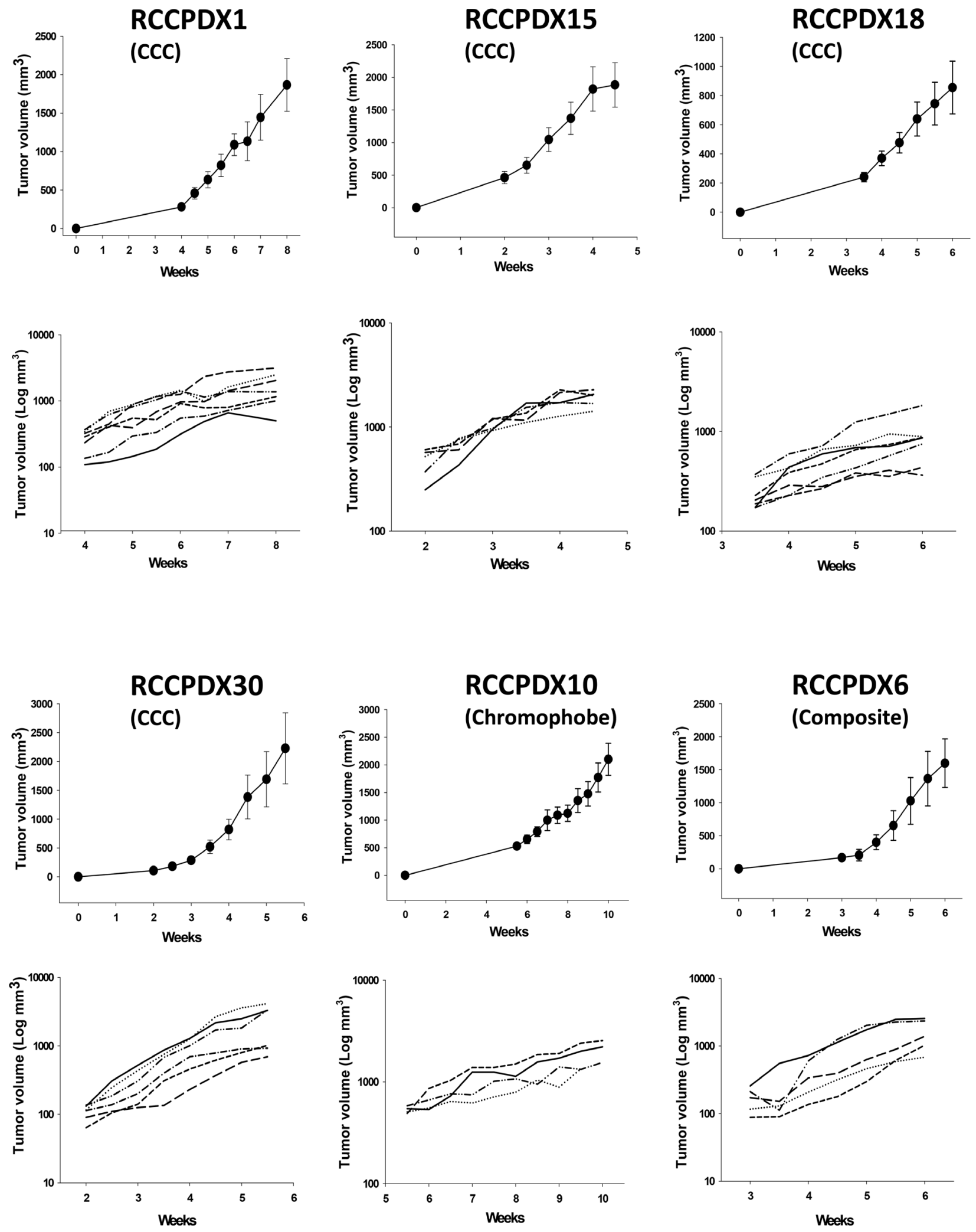

Figure 2: In vivo growth curves of 6 RCCPDX tumors after implantation in nude mice. Curves are shown for 4 RCCPDX of the CCC subtype, 1 RCCPDX of the chromophobe subtype and 1 composite RCCPDX. Top graph, growth curve for each RCCPDX expressed with linear Y scale axis; bottom graph, growth curve for each individual mouse expressed with Y axis in Log scale showing the stable behavior of tumor growth. X-axis: days after implantation; Y-axis: tumor volume in $\mathrm{mm}^{3} . \mathrm{n}=4$ to 7 . Note: For RCCPDX1, RCCPDX15 and RCCPDX30, mice were euthanized when tumor volume reached the ethical $2000 \mathrm{~mm}^{3}$. 
Histopathology analysis of all models showed that the histological features were preserved during passages as compared to the corresponding primary tumor, including tumor architecture, sarcomatoid components, cytology and Fuhrman grade. Similarly, at the genetic level, STR analysis of all models showed only minor changes, as well as a high rate of $\mathrm{Y}$ chromosome loss, as expected from previous studies [24, 25, 35, 36]. Molecular analysis using Affymetrix cDNA arrays performed on a subset of RCCPDX models obtained at different times also revealed the stability of the models compared to the corresponding primary tumor. The analysis of the differentially expressed genes did not allow the definition of a particular molecular signature, that could for example influence engraftment. Such investigations will necessitate the analysis of a large number of tumors that successfully grow in mice vs. tumors that do not grow, and compare them eventually to previous studies where molecular data and analysis are available. This was not the scope of the present work.

Higher stage, grade and sarcomatoid differentiation were among the parameters we studied that favor engraftment. Here, we obtained an engraftment success rate of $8.9 \%$ by xenografting tumors of all sub-types and at all stages and grades, and all tumors were established as transplantable tumors for at least 13 passages. In previous papers from other investigators, in which authors xenografted from 2 to 94 tumors including in some instances metastasis, the engraftment rates ranged between 37 and $100 \%$ [23-34]. This was of course dependent on the size of the cohort, the number of passages in mice, and on the characteristics of the implanted tumors (pTNM stage, tumor size, Fuhrman grade, primary vs. metastatic tissue, unilateral or bilateral cancer and focal or multifocal tumor). For example, in Angevin, et al. publication [30], tumorigenicity was correlated with the metastatic phenotype of the tumor (54\% success rate) and with reduced survival of patients; in Sivanand, et al. publication [28] metastatic tissues engrafted at higher rate than those from primary tissues, and the stability of the engraftment correlated with decreased patient survival.

In the present study, clinical history and followup were available for all patients. Primary tumors and corresponding models were characterized at various biological levels and shown to be stable. Importantly, nude mice bearing some PDX tumors were specifically treated with current therapies (sunitinib, sorafenib and everolimus) to assess their sensitivity and the concordance with the clinical situation. When challenged to current

\section{Tumorgrafts}

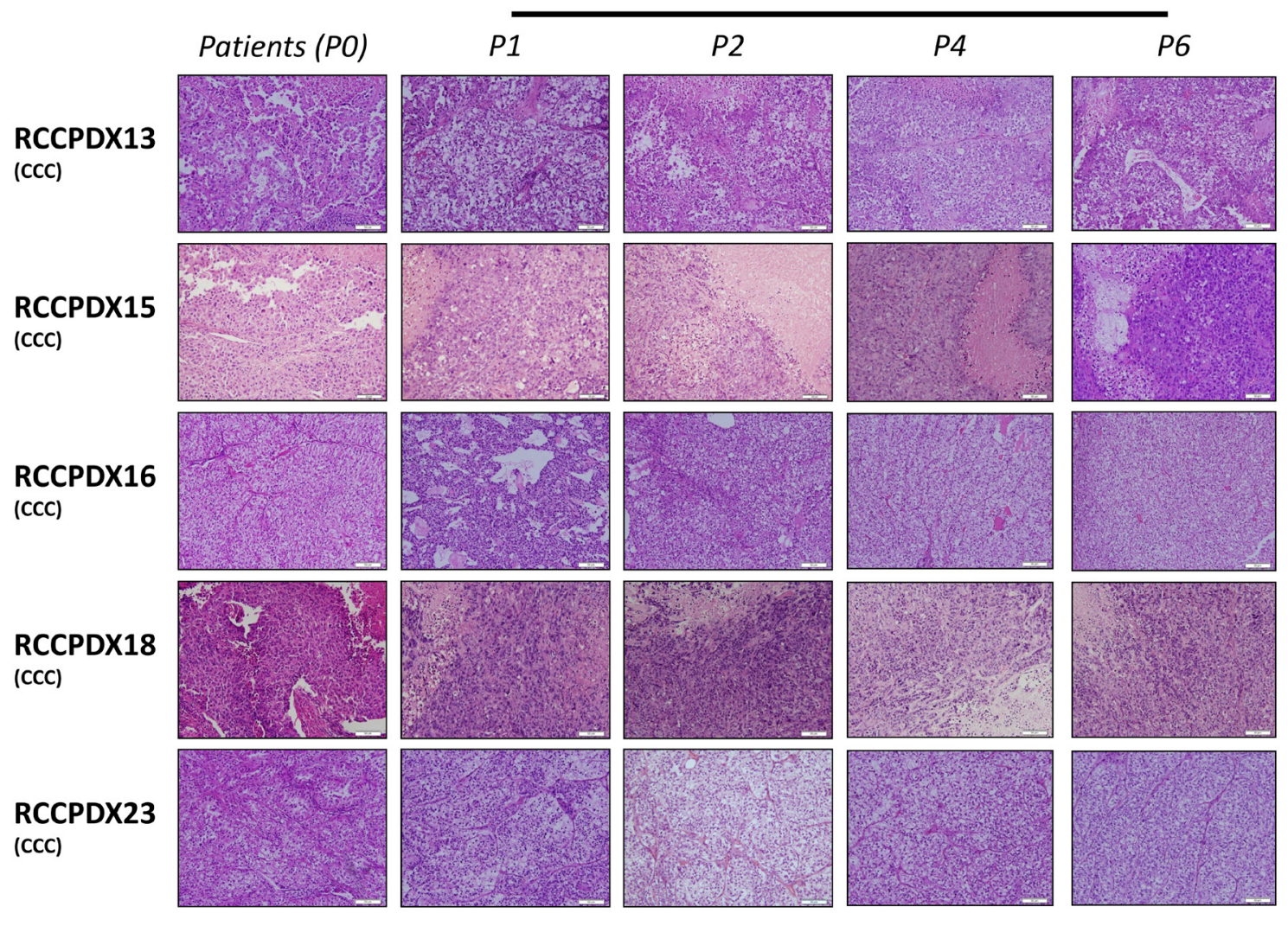

Figure 3: Histologic characterization of RCCPDX models. Representative hematoxylin and eosin sections (x 400) of 5 RCCPDX tumors of the CCC subtype comparing the original patient tumor (P0) to 4 passages in mice. P1, first xenograft in mice; $\mathrm{P} 2$, second xenograft in mice; P4, fourth xenograft in mice and P6, sixth xenograft in mice. 
Table 3: Histological analysis of RCCPDX models and corresponding original tumor

\begin{tabular}{|c|c|c|c|c|}
\hline ID & Passage & Histology & GRADE & $\begin{array}{l}\text { Architecture } \\
\text { Cytoplasmic features }\end{array}$ \\
\hline \multirow{6}{*}{ RCCPDX1 } & 0 & clear cell & 3 & acidophilic / tubular / acinar \\
\hline & 3 & clear cell & 4 & clear acidophilic \\
\hline & 4 & clear cell & 3 & acidophilic / clear \\
\hline & 5 & clear cell with $80 \%$ sarcomatoid & 4 & acidophilic / spindle cell \\
\hline & 6 & clear cell with $80 \%$ sarcomatoid & 4 & acidophilic / spindle cell \\
\hline & 7 & clear cell with $70 \%$ sarcomatoid & 4 & acidophilic / spindle cell \\
\hline \multirow{13}{*}{ RCCPDX2 } & 0 & $\begin{array}{l}\text { poorly differenciated carcinoma with }<1 \% \\
\text { sarcomatoid }\end{array}$ & 4 & acidophilic \\
\hline & 1 & $\begin{array}{l}\text { poorly differenciated carcinoma with }<1 \% \\
\text { sarcomatoid }\end{array}$ & 4 & acidophilic / clear \\
\hline & 2 & $\begin{array}{l}\text { poorly differenciated carcinoma with }<1 \% \\
\text { sarcomatoid }\end{array}$ & 4 & acidophilic / clear \\
\hline & 3 & $\begin{array}{l}\text { poorly differenciated carcinoma with } 50 \% \\
\text { sarcomatoid }\end{array}$ & 4 & acidophilic / spindle cell \\
\hline & 4 & $\begin{array}{l}\text { poorly differenciated carcinoma with } 90 \% \\
\text { sarcomatoid }\end{array}$ & 4 & acidophilic / spindle cell \\
\hline & 5 & $\begin{array}{l}\text { poorly differenciated carcinoma with } 100 \% \\
\text { sarcomatoid }\end{array}$ & 4 & acidophilic / spindle cell \\
\hline & 6 & $\begin{array}{l}\text { poorly differenciated carcinoma with } 90 \% \\
\text { sarcomatoid }\end{array}$ & 4 & acidophilic / spindle cell \\
\hline & 7 & $\begin{array}{l}\text { poorly differenciated carcinoma with } 100 \% \\
\text { sarcomatoid }\end{array}$ & 4 & acidophilic / spindle cell \\
\hline & 8 & $\begin{array}{l}\text { poorly differenciated carcinoma with } 50 \% \\
\text { sarcomatoid }\end{array}$ & 4 & acidophilic / spindle cell \\
\hline & 9 & $\begin{array}{l}\text { poorly differenciated carcinoma with } 10 \% \\
\text { sarcomatoid }\end{array}$ & 4 & acidophilic / spindle cell \\
\hline & 10 & poorly differenciated carcinoma & 4 & acidophilic \\
\hline & 11 & poorly differenciated carcinoma & 4 & acidophilic \\
\hline & 12 & $\begin{array}{l}\text { poorly differenciated carcinoma with } 50 \% \\
\text { sarcomatoid }\end{array}$ & 4 & acidophilic / spindle cell \\
\hline \multirow{10}{*}{ RCCPDX3 } & 0 & clear cell with $20 \%$ sarcomatoid & 3 & acidophilic /clear \\
\hline & 4 & clear cell & 3 & acidophilic / clear \\
\hline & 5 & clear cell & 4 & acidophilic / clear \\
\hline & 6 & clear cell & 3 & acidophilic / acinar \\
\hline & 7 & clear cell & 3 & acidophilic / acinar \\
\hline & 8 & clear cell with $10 \%$ sarcomatoid & 4 & acidophilic / spindle cell \\
\hline & 9 & clear cell & 3 & acidophilic / acinar \\
\hline & 10 & clear cell & 3 & acidophilic / acinar \\
\hline & 11 & clear cell & 3 & acidophilic / acinar \\
\hline & 12 & clear cell with $<10 \%$ sarcomatoid & 4 & acidophilic / spindle cell \\
\hline \multirow{4}{*}{ RCCPDX4 } & 0 & clear cell & 2 & clear/ acinar \\
\hline & 1 & clear cell & 3 & acidophilic \\
\hline & 2 & clear cell & 3 & acidophilic \\
\hline & 3 & clear cell & 3 & acidophilic / acinar \\
\hline \multirow{3}{*}{ RCCPDX5 } & 0 & clear cell & 3 & clear / acidophilic \\
\hline & 1 & clear cell & 2 & clear \\
\hline & 2 & clear cell & 3 & clear \\
\hline
\end{tabular}

(Continued) 


\begin{tabular}{|c|c|c|c|c|}
\hline ID & Passage & Histology & GRADE & $\begin{array}{l}\text { Architecture } \\
\text { Cytoplasmic features }\end{array}$ \\
\hline \multirow{3}{*}{ RCCPDX6 } & 0 & $\begin{array}{l}\text { mixed papillary } 2(50 \%) \text {, clear }(30 \%) \text { with } \\
20 \% \text { sarcomatoid }\end{array}$ & 3 & $\begin{array}{l}\text { acidophilic / clear / acinar / tubular/ } \\
\text { spindle cell }\end{array}$ \\
\hline & 2 & mixed papillary 2 , clear with sarcomatoid & 3 & acidophilic / clear / spindle cell \\
\hline & 3 & clear cell & 3 & acidophilic / clear / acinar / tubular \\
\hline \multirow{11}{*}{ RCCPDX7 } & 0 & clear cell & 3 & clear / acidophilic / acinar / tubular \\
\hline & 1 & clear cell & 3 & acidophilic / clear \\
\hline & 2 & clear cell & 3 & acidophilic / clear \\
\hline & 3 & clear cell & 3 & clear / acidophilic \\
\hline & 4 & clear cell & 3 & clear / acidophilic \\
\hline & 5 & clear cell & 3 & clear / acidophilic \\
\hline & 6 & clear cell & 3 & clear / acidophilic \\
\hline & 7 & clear cell & 4 & acidophilic / clear \\
\hline & 8 & clear cell & 4 & acidophilic / clear \\
\hline & 9 & clear cell & 3 & clear / acidophilic \\
\hline & 10 & clear cell & 3 & acidophilic / clear \\
\hline \multirow{12}{*}{ RCCPDX8 } & 11 & clear cell & 4 & acidophilic / clear \\
\hline & 0 & clear cell with $15 \%$ sarcomatoid & 4 & clear / acidophilic / spindle cell \\
\hline & 1 & clear cell & 3 & acidophilic / clear \\
\hline & 2 & clear cell & 4 & clear / acidophilic \\
\hline & 3 & clear cell & 2 & acidophilic / acinar \\
\hline & 4 & clear cell & 4 & acidophilic / clear \\
\hline & 5 & clear cell & 3 & clear / acidophilic \\
\hline & 6 & clear cell with $90 \%$ sarcomatoid & 4 & acidophilic / spindle cell \\
\hline & 7 & clear cell & 4 & clear / acidophilic \\
\hline & 8 & clear cell with $50 \%$ sarcomatoid & 4 & acidophilic / spindle cell \\
\hline & 9 & clear cell with $50 \%$ sarcomatoid & 4 & acidophilic / spindle cell \\
\hline & 10 & clear cell with $50 \%$ sarcomatoid & 4 & acidophilic / spindle cell \\
\hline \multirow{4}{*}{ RCCPDX9 } & 0 & clear cell with $30 \%$ sarcomatoid & 4 & acidophilic / spindle cell \\
\hline & 1 & clear cell & 4 & clear \\
\hline & 2 & clear cell with rhabdoid & 4 & clear / acidophilic \\
\hline & 3 & clear cell with $80 \%$ sarcomatoid & 4 & clear / acidophilic spindle cell \\
\hline \multirow{9}{*}{ RCCPDX10 } & 0 & chromophobe with $80 \%$ sarcomatoid & 4 & $\begin{array}{l}\text { acidophilic spindle cell } 80 \% \text { and } \\
\text { chromophobe }\end{array}$ \\
\hline & 1 & $100 \%$ sarcomatoid & 4 & acidophilic / spindle cell \\
\hline & 2 & $100 \%$ sarcomatoid & 4 & acidophilic / spindle cell \\
\hline & 3 & $100 \%$ sarcomatoid & 4 & acidophilic / spindle cell \\
\hline & 4 & $100 \%$ sarcomatoid & 4 & acidophilic / spindle cell \\
\hline & 5 & $100 \%$ sarcomatoid & 4 & acidophilic / spindle cell \\
\hline & 6 & $100 \%$ sarcomatoid & 4 & acidophilic / spindle cell \\
\hline & 7 & $100 \%$ sarcomatoid & 4 & acidophilic / spindle cell \\
\hline & 8 & $100 \%$ sarcomatoid & 4 & acidophilic / spindle cell \\
\hline \multirow{4}{*}{ RCCPDX11 } & 0 & clear cell with $50 \%$ sarcomatoid & 4 & clear / acidophilic / spindle cell \\
\hline & 1 & clear cell with sarcomatoid & 4 & acidophilic / clear / spindle cell \\
\hline & 2 & clear cell with sarcomatoid & 4 & acidophilic / clear / spindle cell \\
\hline & 3 & clear cell with sarcomatoid & 4 & acidophilic / clear / spindle cell \\
\hline
\end{tabular}

(Continued) 


\begin{tabular}{|c|c|c|c|c|}
\hline ID & Passage & Histology & GRADE & $\begin{array}{l}\text { Architecture } \\
\text { Cytoplasmic features }\end{array}$ \\
\hline \multirow{3}{*}{ RCCPDX12 } & 0 & clear cell & 2 & clear \\
\hline & 1 & clear cell & 3 & clear / acinar \\
\hline & 2 & clear cell & 3 & clear / acinar \\
\hline \multirow{7}{*}{ RCCPDX13 } & 0 & clear cell with rhabdoid & 4 & acidophilic / clear \\
\hline & 1 & clear cell with rhabdoid & 2 & acidophilic / clear \\
\hline & 2 & clear cell with rhabdoid & 4 & acidophilic / clear \\
\hline & 3 & clear cell with rhabdoid & 4 & acidophilic / clear / acinar \\
\hline & 4 & clear cell with rhabdoid & 4 & acidophilic \\
\hline & 6 & clear cell with rhabdoid & 4 & clear / acidophilic \\
\hline & 7 & clear cell with $20 \%$ rhabdoid & 4 & acidophilic / clear / acinar \\
\hline \multirow{6}{*}{ RCCPDX14 } & 0 & clear cell & 3 & clear / acidophilic / acinar / tubular \\
\hline & 1 & clear cell & 3 & clear / acidophilic / acinar / tubular \\
\hline & 2 & clear cell & 2 & clear / acidophilic / acinar \\
\hline & 3 & clear cell & 3 & clear / acidophilic / acino / tubular \\
\hline & 4 & clear cell & 3 & clear / acidophilic / acino / tubular \\
\hline & 5 & clear cell & 3 & clear / acidophilic / acinar / tubular \\
\hline \multirow{11}{*}{ RCCPDX15 } & 0 & clear cell with $15 \%$ sarcomatoid & 4 & $\begin{array}{l}\text { acidophilic / acinar / tubular / spindle } \\
\text { cell }\end{array}$ \\
\hline & 1 & clear cell & 4 & acidophilic / acinar \\
\hline & 2 & clear cell & 3 & acidophilic / acinar and diffuse \\
\hline & 3 & clear cell & 4 & acidophilic \\
\hline & 4 & clear cell with $50 \%$ sarcomatoid & 4 & Acidophilic / spindle cell \\
\hline & 5 & clear cell & 4 & acidophilic \\
\hline & 6 & clear cell & 3 & acidophilic \\
\hline & 7 & clear cell & 4 & acidophilic \\
\hline & 8 & clear cell & 4 & acidophilic \\
\hline & 9 & clear cell & 4 & acidophilic \\
\hline & 10 & clear cell & 4 & acidophilic \\
\hline \multirow{7}{*}{ RCCPDX16 } & 0 & clear cell & 2 & clear / acidophilic acinar \\
\hline & 1 & clear cell & 2 & clear / acidophilic / acinar / tubular \\
\hline & 2 & clear cell & 2 & clear / acidophilic / acinar \\
\hline & 3 & clear cell & 2 & clear / acinar / tubular \\
\hline & 4 & clear cell & 2 & clear / acidophilic \\
\hline & 5 & clear cell & 2 & clear \\
\hline & 6 & clear cell & 2 & clear / acidophilic \\
\hline \multirow{11}{*}{ RCCPDX17 } & 0 & clear cell & 2 & clear / acidophilic / acinar / tubular \\
\hline & 1 & clear cell & 3 & acidophilic and diffuse \\
\hline & 2 & clear cell & 3 & acidophilic / acinar / tubular \\
\hline & 3 & clear cell & 2 & clear / acidophilic / acinar / tubular \\
\hline & 4 & clear cell & 2 & acidophilic / acinar / tubular \\
\hline & 5 & clear cell & 3 & acidophilic / tubular \\
\hline & 6 & clear cell & 2 & acidophilic / tubular \\
\hline & 7 & clear cell & 2 & acidophilic / clear / acinar \\
\hline & 8 & clear cell & 2 & acidophilic / acinar \\
\hline & 0 & clear cell with $20 \%$ sarcomatoid & 4 & acidophilic / spindle cell \\
\hline & 1 & clear cell with sarcomatoid & 4 & $\begin{array}{l}\text { acidophilic / acinar and diffuse / } \\
\text { spindle cell }\end{array}$ \\
\hline
\end{tabular}

(Continued) 


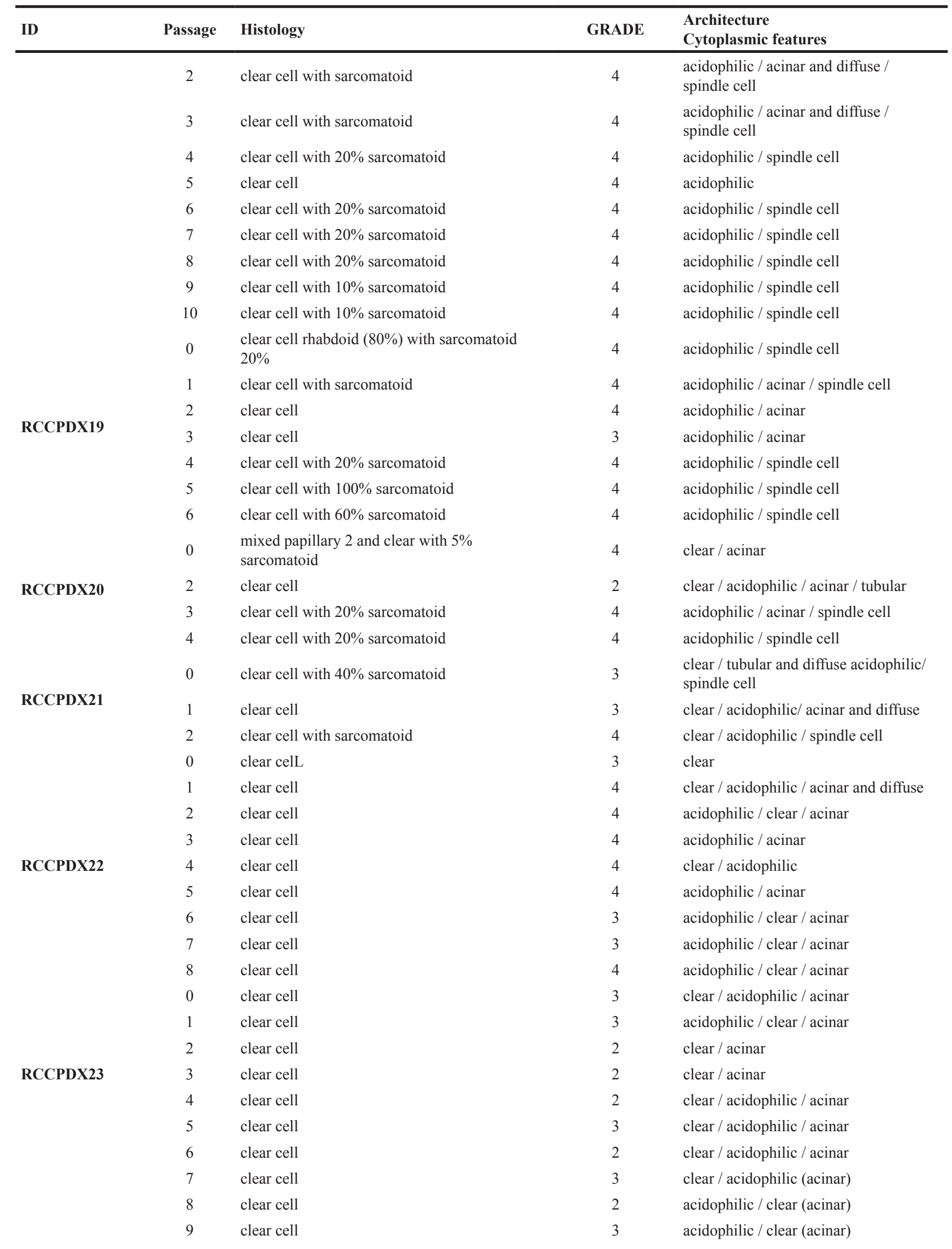

(Continued) 


\begin{tabular}{|c|c|c|c|c|}
\hline ID & Passage & Histology & GRADE & $\begin{array}{l}\text { Architecture } \\
\text { Cytoplasmic features }\end{array}$ \\
\hline \multirow{13}{*}{ RCCPDX24 } & 10 & clear cell & 2 & clear / acidophilic (acinar) \\
\hline & 0 & unclassified with $100 \%$ sarcomatoid & 4 & acidophilic / spindle cell \\
\hline & 1 & unclassified with sarcomatoid & 4 & acidophilic / spindle cell \\
\hline & 2 & unclassified with sarcomatoid & 4 & acidophilic / spindle cell \\
\hline & 3 & unclassified with sarcomatoid & 4 & acidophilic / spindle cell \\
\hline & 4 & unclassified with sarcomatoid & 4 & acidophilic / spindle cell \\
\hline & 5 & unclassified with sarcomatoid & 4 & acidophilic / spindle cell \\
\hline & 6 & unclassified with sarcomatoid & 4 & acidophilic / spindle cell \\
\hline & 7 & unclassified with sarcomatoid & 4 & acidophilic / spindle cell \\
\hline & 8 & unclassified with sarcomatoid & 4 & acidophilic / spindle cell \\
\hline & 9 & unclassified with sarcomatoid & 4 & acidophilic / spindle cell \\
\hline & 10 & unclassified with sarcomatoid & 4 & acidophilic / spindle cell \\
\hline & 0 & clear cell & 3 & clear / acidophilic / tubular / acinar \\
\hline \multirow{6}{*}{ RCCPDX25 } & 1 & clear cell & 3 & clear \\
\hline & 2 & clear cell & 3 & clear \\
\hline & 3 & clear cell & 3 & clear \\
\hline & 4 & clear cell & 3 & clear / acidophilic \\
\hline & 5 & clear cell & 4 & clear / acidophilic \\
\hline & 6 & clear cell & 4 & clear / acidophilic \\
\hline \multirow{10}{*}{ RCCPDX26 } & 7 & clear cell & 4 & clear / acidophilic \\
\hline & 0 & clear cell & 3 & clear \\
\hline & 1 & clear cell & 4 & clear / acinar \\
\hline & 2 & clear cell & 3 & clear / acidophilic / acinar \\
\hline & 3 & clear cell & 3 & clear / acidophilic / acinar \\
\hline & 4 & clear cell & 3 & clear / acidophilic / acinar \\
\hline & 5 & clear cell & 4 & clear / acidophilic / acinar \\
\hline & 6 & clear cell & 4 & clear / acidophilic / acinar \\
\hline & 7 & clear cell & 3 & clear / acinar \\
\hline & 0 & medullary carcinoma & NA & acidophilic sheets \\
\hline \multirow{4}{*}{ RCCPDX27 } & 1 & medullary carcinoma & NA & acidophilic sheets \\
\hline & 2 & medullary carcinoma & NA & acidophilic sheets \\
\hline & 3 & medullary carcinoma & NA & acidophilic sheets \\
\hline & 4 & medullary carcinoma & NA & acidophilic sheets \\
\hline \multirow{6}{*}{ RCCPDX28 } & 5 & medullary carcinoma & NA & acidophilic sheets \\
\hline & 0 & clear cell & 4 & acidophilic / clear \\
\hline & 1 & clear cell & 4 & acidophilic / clear \\
\hline & 2 & clear cell & 4 & acidophilic / clear \\
\hline & 3 & clear cell & 3 & acidophilic / clear \\
\hline & 0 & papillary type 2 & 3 & papillary \\
\hline \multirow{3}{*}{ RCCPDX29 } & 1 & papillary type 2 & 3 & papillary \\
\hline & 2 & papillary type 2 & 3 & papillary \\
\hline & 3 & papillary type 2 & 3 & papillary \\
\hline \multirow{4}{*}{ RCCPDX30 } & 0 & clear cell & 4 & clear / acidophilic / acinar / tubular \\
\hline & 1 & clear cell & 4 & acidophilic / clear / acinar \\
\hline & 2 & clear cell & 4 & acidophilic / clear / acinar \\
\hline & 3 & clear cell & 4 & acidophilic / clear / acinar \\
\hline
\end{tabular}


targeted therapies, each model behaved differently depending on the respective therapy. Importantly, when available, the models responded to the therapy exactly as the patient from whom the xenograft was derived. However, in a clinical point of view, all patients are treated the same way since no predictive biomarkers have yet been validated for these drugs as well as for new potential therapeutic compounds currently under clinical evaluation. This lack of biomarkers restricts our ability to tailor specific drugs to patients and might be considered as the most important barrier for a better clinical response.

It should be stressed, however, that in the present study only one model, and another but derived from a metastatic site (not included in the RCCPDX panel presented here) were available to assess whether the models generated may have predictivity value, i.e similar or identical therapeutic response than the parental tumor. The results obtained with these two models are therefore not conclusive regarding predictivity of the therapeutic response. However, these models reproduce the sensitivity to targeted therapies observed in the clinic, thus closely mimicking human RCC.
Thus, this panel of RCCPDX models should be valuable for studying the mechanisms of therapy-induced resistance, and for the design of prognostic tools based on molecular signatures of the tumors, which should help to better design therapy tailored to the patient. This is clearly of great value to identify predictive biomarkers of therapeutic response and of therapy-induced resistance. Moreover, these PDX models could be used for screening any new emerging treatment for RCC, as well as for repositioning existing drugs, allowing for a rapid and cost efficient screening of response biomarkers that will be the base of personalized medicine.

RCC tumor grafts have been successfully generated by some independent groups by xenografting primary and/or metastastic tissues [23-34]. The PDX generated were comparable to parental tumors, at least with regard to the parameters analyzed including histology, genetic and molecular features. When available, metastatic and drug responsiveness recapitulated what is observed in clinic. The comparison between our work and that of these other groups may be quite difficult since the panel of tumors xenografted differs from one study to another as well as the number of passages, from 1 to 50 , and the

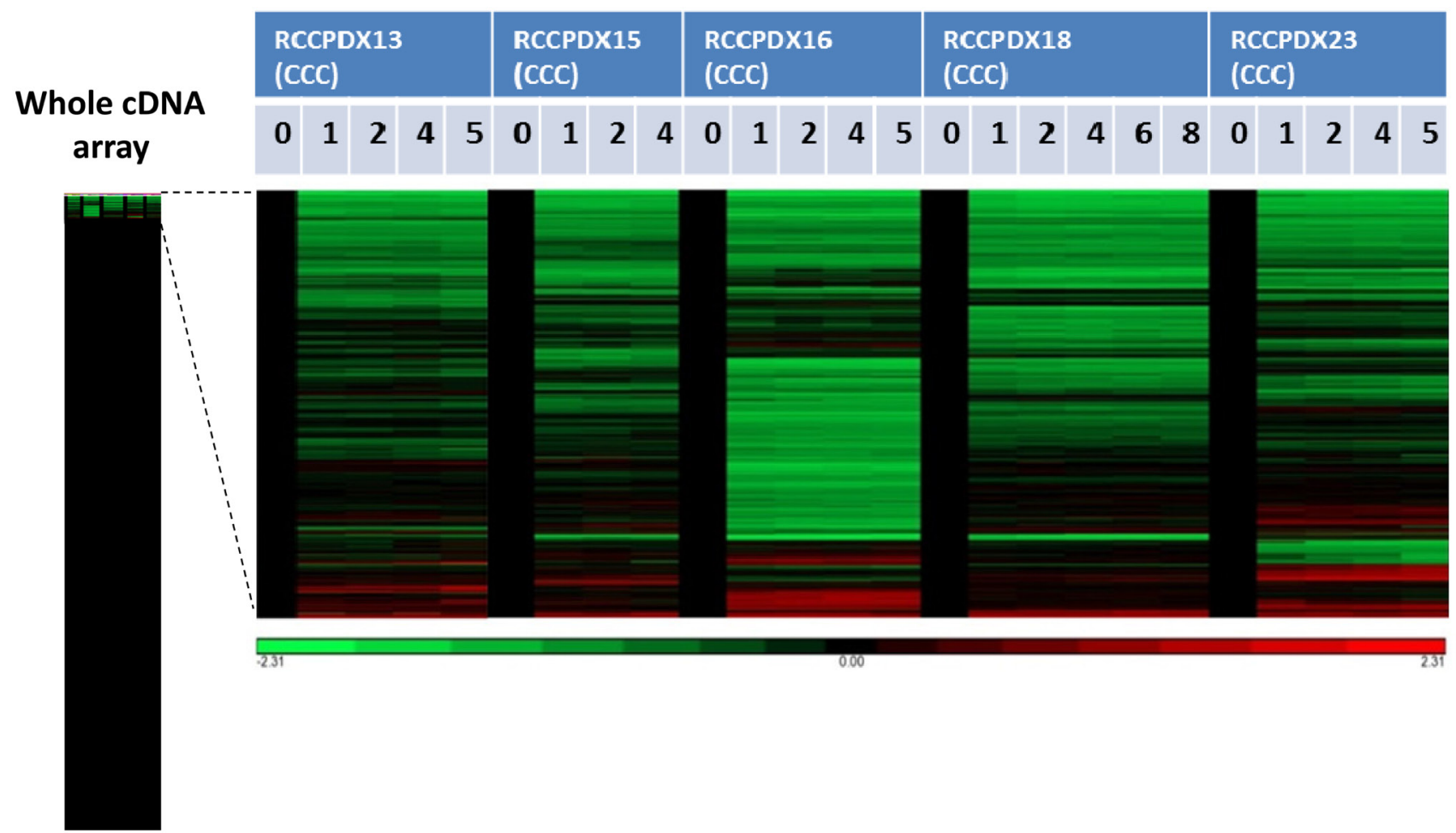

Figure 4: Affymetrix analysis of 5 RCCPDX tumors of the CCC subtype comparing the whole transcriptome of the original patient tumor (P0) to 3 to 5 passages (P1 to P8) in mice. Gene expression in the various passages was compared to P0 that was set to 1 and appears in black. The left bar shows the whole analysis of cDNA array and the genes that were differentially expressed in passages compared to $\mathrm{P} 0$ are enlarged on the right. In green, genes that were overexpressed compared to $\mathrm{P} 0$ and in red, genes that were underexpressed compared to P0. Only a subset of genes were differentially expressed in passages compared to P0, and the differences were stable among passages for each RCCPDX (please see text for more details). 
Table 4: Common differentially expressed genes in the 5 RCCPDX analyzed by Affymetrix

\section{Up-regulated gene}

Hemoglobin, epsilon 1, mRNA

\section{Down-regulated genes}

Alpha-2-macroglobulin

Chromosome 13 open reading frame 15

Chromosome 16 open reading frame 54

Complement component 1, q subcomponent, B chain

Complement component 1, q subcomponent, $\mathrm{C}$ chain

CD163 molecule

CD52 molecule

CD93 molecule

Collagen, type XV, alpha 1

Endothelin receptor type $\mathrm{B}$

EGF, latrophilin and seven transmembrane domain containing 1

Gtpase, IMAP family member 4

Gtpase, IMAP family member 6

G protein-coupled receptor 116

Major histocompatibility complex, class II, DQ alpha 1

Immunoglobulin heavy locus constant gamma 1 (G1m marker)

Lymphocyte cytosolic protein 2 (SH2 domain containing leukocyte protein of $76 \mathrm{kda}$ )

LIM domain binding 2

Immunoglobulin-like transcript $2 \mathrm{~b}$

Leukocyte immunoglobulin-like receptor, subfamily B (with TM and ITIM domains), member

Lysozyme (renal amyloidosis)

Myeloid cell nuclear differentiation antigen

Macrophage expressed 1

Membrane-spanning 4-domains, subfamily A, member 4

Membrane-spanning 4-domains, subfamily A, member 7

Platelet/endothelial cell adhesion molecule

Protein tyrosine phosphatase, receptor type, $\mathrm{C}$

Regulator of G-protein signaling 1

Ribonuclease, rnase A family, k6

SAM domain, SH3 domain and nuclear localization signals 1

T-cell activation rho GTPase activating protein

TYRO protein tyrosine kinase binding protein 
Table 5: Short tandem repeat fingerprinting

\begin{tabular}{|c|c|c|c|c|c|c|c|c|c|c|}
\hline RCCPDX ID & AMEL & D10S1248 & D12S391 & D19S433 & D1S1656 & D22S1045 & D2S1338 & D2S441 & D6S1043 & TH01 \\
\hline RCCPDX1/P0 & $X, Y$ & 12 & $19 ; 22$ & $13 ; 14$ & $11 ; 14$ & $13 ; 14$ & 24 & 9,1 & $12 ; 19$ & $8 ; 9,3$ \\
\hline RCCPDX1/P1 & $\mathrm{X}$ & $13 ; 14$ & $19 ; 22$ & $13 ; 14$ & $11 ; 14$ & 15 & 24 & $10 ; 11,3$ & 12 & $8 ; 9,3$ \\
\hline RCCPDX1/P4 & $\mathrm{X}$ & $13 ; 14$ & $19 ; 22$ & $13 ; 14$ & $11 ; 14$ & 15 & 24 & $10 ; 11,3$ & 12 & $8 ; 9,3$ \\
\hline RCCPDX2 /P0 & $\mathrm{X}, \mathrm{Y}$ & 13 & 19,$1 ; 19,3$ & $14 ; 15$ & 11 & $15 ; 17$ & $20 ; 25$ & $14 ; 15$ & 17 & $8 ; 9$ \\
\hline RCCPDX2 /P1 & $X, Y$ & 13,14 & 19,$1 ; 19,3$ & $14 ; 15$ & 11 & 17 & $20 ; 25$ & $14 ; 15$ & $12 ; 17$ & $8 ; 9$ \\
\hline RCCPDX2 /P4 & $\mathrm{X}, \mathrm{Y}$ & 13 & 19,$1 ; 19,3$ & $14 ; 15$ & 11 & 17 & $20 ; 25$ & $14 ; 15$ & 17 & $8 ; 9$ \\
\hline RCCPDX3 /P0 & $\mathrm{X}, \mathrm{Y}$ & $14 ; 15$ & $17 ; 18$ & $13 ; 14$ & $12 ; 16$ & 15 & $17 ; 20$ & 10 & 11 & 6 \\
\hline RCCPDX3 /P1 & $\mathrm{X}$ & $14 ; 15$ & $17 ; 18$ & $13 ; 14$ & $12 ; 16$ & 15 & $17 ; 20$ & 10 & 11 & 6 \\
\hline RCCPDX3 /P4 & $\mathrm{X}$ & $14 ; 15$ & $17 ; 18$ & $13 ; 14$ & $12 ; 16$ & 15 & $17 ; 20$ & 10 & $11 ; 13$ & 6 \\
\hline RCCPDX4 /P0 & $\mathrm{X}$ & $13 ; 14 ; 15$ & $17 ; 22$ & $14 ; 15$ & $15 ; 18,3$ & $15 ; 16$ & $17 ; 19$ & $10 ; 11$ & $12 ; 17$ & $8 ; 9$ \\
\hline RCCPDX4 /P1 & $\mathrm{X}$ & $13 ; 14 ; 15$ & $17 ; 22$ & $14 ; 15$ & $15 ; 18,3$ & $15 ; 16$ & $17 ; 19$ & $10 ; 11$ & $12 ; 17$ & $8 ; 9$ \\
\hline RCCPDX4 /P3 & $\mathrm{X}$ & $13 ; 14 ; 15$ & $17 ; 22$ & $14 ; 15$ & $15 ; 18,3$ & $15 ; 16$ & $17 ; 19$ & $10 ; 11$ & $12 ; 17$ & $8 ; 9$ \\
\hline RCCPDX5 /P0 & $\mathrm{X}, \mathrm{Y}$ & $13 ; 14 ; 15$ & $15 ; 24$ & $12 ; 16$ & $12 ; 15$ & $15 ; 16$ & 17 & 11,$3 ; 14$ & $11 ; 18$ & 9,3 \\
\hline RCCPDX5 /P2 & $\mathrm{X}, \mathrm{Y}$ & $13 ; 14 ; 15$ & $15 ; 24$ & $12 ; 16$ & $12 ; 15$ & $15 ; 16$ & 17 & 11,$3 ; 14$ & $11 ; 18$ & 9,3 \\
\hline RCCPDX5 /P4 & $\mathrm{X}, \mathrm{Y}$ & $13 ; 14 ; 15$ & $15 ; 24$ & $12 ; 16$ & $12 ; 15$ & $15 ; 16$ & 17 & 11,$3 ; 14$ & $11 ; 18$ & 9,3 \\
\hline RCCPDX6/P0 & $\mathrm{X}, \mathrm{Y}$ & $13 ; 14$ & $17 ; 21$ & 14 & $15 ; 17$ & $11 ; 16$ & $19 ; 24$ & $10 ; 14$ & $12 ; 17$ & 9,3 \\
\hline RCCPDX6/P1 & $\mathrm{X}$ & $13 ; 14$ & $17 ; 21$ & 14 & 17 & 16 & $19 ; 24$ & $10 ; 14$ & 12 & 9,3 \\
\hline RCCPDX6/P3 & $\mathrm{X}$ & $13 ; 14$ & $17 ; 21$ & 14 & 17 & 16 & $19 ; 24$ & $10 ; 14$ & 12 & 9,3 \\
\hline RCCPDX7 /P0 & $\mathrm{X}, \mathrm{Y}$ & $15 ; 16$ & $17 ; 22$ & $14 ; 15$ & 16 & $14 ; 15$ & $17 ; 23$ & $11 ; 11,3$ & $11 ; 14$ & $8 ; 9,3$ \\
\hline RCCPDX7 /P1 & $\mathrm{X}$ & 15 & 17 & $14 ; 15$ & 16 & $14 ; 15$ & 17 & $11 ; 11,3$ & $11 ; 14$ & $8 ; 9,3$ \\
\hline RCCPDX7 /P4 & $\mathrm{X}$ & 15 & 17 & $14 ; 15$ & 16 & $14 ; 15$ & 17 & $11 ; 11,3$ & $11 ; 14$ & $8 ; 9,3$ \\
\hline RCCPDX8 /P0 & $\mathrm{X}, \mathrm{Y}$ & $13 ; 15$ & $19 ; 23$ & $12 ; 13$ & 17,$3 ; 18,3$ & $15 ; 16$ & 25 & 14 & 11 & 9 \\
\hline RCCPDX8 /P1 & $\mathrm{X}$ & $13 ; 15$ & $19 ; 23$ & $12 ; 13$ & 17,$3 ; 18,3$ & $15 ; 16$ & 25 & 14 & 11 & 9 \\
\hline RCCPDX8 /P4 & $\mathrm{X}$ & $13 ; 15$ & $19 ; 23$ & $12 ; 13$ & 17,$3 ; 18,3$ & $15 ; 16$ & 25 & 14 & 11 & 9 \\
\hline RCCPDX9 /P0 & $X, Y$ & 13.15 & $15 ; 21$ & $13 ; 14$ & 15 & 15 & $17 ; 26$ & $11 ; 14$ & $11 ; 20$ & 6 \\
\hline RCCPDX9/P1 & $\mathrm{X}$ & 13.15 & $15 ; 21$ & $13 ; 14$ & 15 & $13 ; 15 ; 19$ & $17 ; 26$ & $11 ; 14$ & $11 ; 22$ & 6 \\
\hline RCCPDX9/P4 & $\mathrm{X}$ & 13.15 & $15 ; 21$ & $13 ; 14$ & 15 & $13 ; 15 ; 19$ & $17 ; 26$ & $11 ; 14$ & $11 ; 22$ & 6 \\
\hline RCCPDX10/P0 & $\mathrm{X}$ & 13 & 23 & $14 ; 15$ & 15 & 15 & 17 & 11 & 11 & $6 ; 8$ \\
\hline RCCPDX10/P1 & $\mathrm{X}$ & 13 & 23 & $14 ; 15$ & 15 & 15 & 17 & 11 & 11 & $6 ; 8$ \\
\hline RCCPDX10/P4 & $\mathrm{X}$ & 13 & 23 & $14 ; 15$ & 15 & 15 & 17 & 11 & 11 & $6 ; 8$ \\
\hline RCCPDX11/P0 & $\mathrm{X}$ & 16 & $17 ; 20$ & 13,$2 ; 14$ & 15 & $14 ; 16$ & $19 ; 24$ & $11 ; 14$ & $12 ; 14$ & $6 ; 7$ \\
\hline RCCPDX11/P1 & $\mathrm{X}$ & 16 & $17 ; 20$ & 13,$2 ; 14$ & 15 & $14 ; 16$ & 24 & $11 ; 14$ & 12 & $6 ; 7$ \\
\hline RCCPDX11/P3 & $\mathrm{X}$ & 16 & $17 ; 20$ & 13,$2 ; 14$ & 15 & $14 ; 16$ & 24 & $11 ; 14$ & 12 & $6 ; 7$ \\
\hline
\end{tabular}

(Continued) 


\begin{tabular}{|c|c|c|c|c|c|c|c|c|c|c|}
\hline RCCPDX ID & AMEL & D10S1248 & D12S391 & D19S433 & D1S1656 & D22S1045 & D2S1338 & D2S441 & D6S1043 & TH01 \\
\hline $\mathrm{RCCPDX} 12 / \mathrm{P} 0$ & $\mathrm{X}$ & $14 ; 15 ; 16$ & $18 ; 22$ & $14 ; 15$ & 13 & $15 ; 16$ & $19 ; 24$ & 11 & $12 ; 13$ & $6 ; 7$ \\
\hline RCCPDX12/P2 & $\mathrm{X}$ & $14 ; 15 ; 16$ & $18 ; 22$ & $14 ; 15$ & 13 & $15 ; 16$ & $19 ; 24$ & 11 & $12 ; 13$ & $6 ; 7$ \\
\hline $\mathrm{RCCPDX} 12 / \mathrm{P} 4$ & $\mathrm{X}$ & $14 ; 15 ; 16$ & $18 ; 22$ & $14 ; 15$ & 13 & $15 ; 16$ & $19 ; 24$ & 11 & $12 ; 13$ & $6 ; 7$ \\
\hline $\mathrm{RCCPDX} 13 / \mathrm{P} 0$ & $\mathrm{X} ; \mathrm{Y}$ & 13 & $17 ; 19$ & $14 ; 15$ & $16 ; 17,3$ & $14 ; 16$ & $23 ; 25$ & $11 ; 15$ & $11 ; 13$ & $7 ; 8$ \\
\hline $\mathrm{RCCPDX} 13 / \mathrm{P} 1$ & $\mathrm{X}$ & 13 & $17 ; 19$ & 14 & $16 ; 17,3$ & 14 & $23 ; 25$ & $11 ; 15$ & 13 & $7 ; 8$ \\
\hline $\mathrm{RCCPDX} 13 / \mathrm{P} 4$ & $\mathrm{X}$ & 13 & $17 ; 19$ & 14 & $16 ; 17,3$ & 14 & $23 ; 25$ & $11 ; 15$ & 13 & $7 ; 8$ \\
\hline RCCPDX14/P0 & $\mathrm{X}, \mathrm{Y}$ & 14 & 20 & 14,$2 ; 16$ & $17 ; 17,3$ & 14 & $24 ; 25$ & $10 ; 11$ & $11 ; 19$ & $9 ; 9,3$ \\
\hline RCCPDX14/P1 & $X, Y$ & 14 & 20 & 14,$2 ; 16$ & $17 ; 17,3$ & 14 & $24 ; 25$ & $10 ; 11$ & $11 ; 19$ & $9 ; 9,3$ \\
\hline RCCPDX14/P4 & $X, Y$ & 14 & 20 & 14,$2 ; 16$ & $17 ; 17,3$ & 14 & $24 ; 25$ & $10 ; 11$ & $11 ; 19$ & $9 ; 9,3$ \\
\hline RCCPDX15/P0 & $\mathrm{X} ; \mathrm{Y}$ & $13 ; 15 ; 16$ & $16 ; 19,3$ & $11 ; 12 ; 14,3 ; 16$ & 16,$3 ; 17,3 ; 18,3$ & $16 ; 17$ & $17 ; 19$ & $9 ; 10 ; 11$ & 10,3 & $8 ; 9,3$ \\
\hline RCCPDX15/P1 & $\mathrm{X} ; \mathrm{Y}$ & $15 ; 16 ; 17$ & $16 ; 19,3$ & $11 ; 12 ; 16$ & 16,$3 ; 17,3 ; 18,3 ; 20,3$ & $16 ; 17$ & $16 ; 19$ & $9 ; 11$ & 10,3 & $8 ; 9,3$ \\
\hline RCCPDX15/P4 & $\mathrm{X} ; \mathrm{Y}$ & $15 ; 16 ; 17$ & $16 ; 18,3 ; 19,3$ & $11 ; 12 ; 16$ & 16,$3 ; 17,3 ; 18,3 ; 20,3$ & $16 ; 17$ & $16 ; 19$ & $9 ; 10 ; 11$ & 10,3 & $8 ; 9,3$ \\
\hline RCCPDX16/P0 & $\mathrm{X} ; \mathrm{Y}$ & $13 ; 16$ & $20 ; 23$ & 14 & $12 ; 16,3$ & $15 ; 16$ & $16 ; 23$ & 11 & $12 ; 14$ & 7 \\
\hline RCCPDX16/P1 & $\mathrm{X}$ & 16 & $20 ; 23$ & 14 & 12 & $15 ; 16$ & 16 & 11 & 12 & 7 \\
\hline $\mathrm{RCCPDX} 16 / \mathrm{P} 4$ & $\mathrm{X}$ & 16 & $20 ; 23$ & 14 & 12 & $15 ; 16$ & 16 & 11 & 12 & 7 \\
\hline $\mathrm{RCCPDX} 17 / \mathrm{P} 0$ & $\mathrm{X}, \mathrm{Y}$ & 16 & $21 ; 23$ & $14 ; 15,2$ & $12 ; 13$ & 15 & $18 ; 23$ & $11 ; 11,3$ & $12 ; 13$ & 9 \\
\hline $\mathrm{RCCPDX} 17 / \mathrm{P} 1$ & $\mathrm{X}$ & 16 & $21 ; 23$ & $14 ; 15,2$ & $12 ; 13$ & 15 & $18 ; 23$ & $11 ; 11,3$ & 12 & 9 \\
\hline $\mathrm{RCCPDX} 17 / \mathrm{P} 4$ & $\mathrm{X}$ & 16 & $21 ; 23$ & $14 ; 15,2$ & $12 ; 13$ & 15 & $18 ; 23$ & $11 ; 11,3$ & 12 & 9 \\
\hline RCCPDX18/P0 & $\mathrm{X}$ & $14 ; 15 ; 16$ & $19 ; 26$ & $12 ; 13$ & $12 ; 16$ & $15 ; 16$ & $19 ; 25$ & $10 ; 11$ & $12 ; 13$ & $9 ; 10$ \\
\hline RCCPDX18/P1 & $\mathrm{X}$ & $14 ; 15 ; 16$ & $19 ; 26$ & $12 ; 13$ & $12 ; 16$ & 15 & 25 & $10 ; 11$ & $12 ; 13$ & $9 ; 10$ \\
\hline RCCPDX18/P3 & $\mathrm{X}$ & $14 ; 15 ; 16$ & $19 ; 26$ & $12 ; 13$ & $12 ; 16$ & 15 & 25 & $10 ; 11$ & $12 ; 13$ & $9 ; 10$ \\
\hline RCCPDX19/P0 & $X, Y$ & 14 & $18 ; 22$ & 14,$2 ; 15$ & $14 ; 16$ & 16 & $17 ; 23$ & $11 ; 14$ & $11 ; 12$ & 6 \\
\hline RCCPDX19/P1 & $\mathrm{X}$ & 14 & 18 & 15 & $14 ; 16$ & 16 & 17 & $11 ; 14$ & $11 ; 12$ & 6 \\
\hline RCCPDX19/P4 & $\mathrm{X}$ & 14 & 18 & 15 & $14 ; 16$ & 16 & 17 & $11 ; 14$ & $11 ; 12$ & 6 \\
\hline $\mathrm{RCCPDX} 20 / \mathrm{P} 0$ & $\mathrm{X}, \mathrm{Y}$ & 13 & $17 ; 25$ & $14 ; 17$ & 15,3 & $11 ; 15$ & 23 & 14 & $14 ; 18$ & $7 ; 9$ \\
\hline RCCPDX20/P1 & $\mathrm{X}, \mathrm{Y}$ & 13 & $17 ; 25$ & $14 ; 17$ & 15,$3 ; 16$ & $11 ; 15$ & 23 & 14 & $14 ; 18$ & $7 ; 9$ \\
\hline RCCPDX20/P4 & $\mathrm{X}, \mathrm{Y}$ & 13 & $17 ; 25$ & $14 ; 17$ & 15,$3 ; 16$ & $11 ; 15$ & 23 & 14 & $14 ; 18$ & $7 ; 9$ \\
\hline $\mathrm{RCCPDX} 21 / \mathrm{P} 0$ & $\mathrm{X}, \mathrm{Y}$ & 14,16 & 18,$3 ; 21$ & 15 & $16 ; 19,3$ & $16 ; 17$ & 17 & $11 ; 14$ & $11 ; 19$ & $6 ; 9$ \\
\hline RCCPDX21/P1 & $\mathrm{X}, \mathrm{Y}$ & 14,16 & 18,$3 ; 21$ & 15 & $16 ; 19,3$ & $16 ; 17$ & 17 & $11 ; 14$ & 19 & $6 ; 9$ \\
\hline RCCPDX21/P2 & $\mathrm{X}, \mathrm{Y}$ & 14,16 & 18,$3 ; 21$ & 15 & $16 ; 19,3$ & $16 ; 17$ & 17 & $11 ; 14$ & 19 & $6 ; 9$ \\
\hline $\mathrm{RCCPDX} 22 / \mathrm{P} 0$ & $\mathrm{X}, \mathrm{Y}$ & $14 ; 15$ & 16,$3 ; 18,3$ & $13 ; 15$ & 16,$3 ; 17,3$ & 15,16 & $17 ; 21$ & $13 ; 14$ & $11 ; 12$ & $7 ; 9,3$ \\
\hline $\mathrm{RCCPDX} 22 / \mathrm{P} 1$ & $X, Y$ & $13 ; 14 ; 15$ & 16,$3 ; 18,3$ & $13 ; 15$ & 16,$3 ; 17,3$ & 15,16 & $17 ; 21$ & $12 ; 14$ & $11 ; 12$ & $7 ; 9,3$ \\
\hline
\end{tabular}

(Continued) 


\begin{tabular}{|c|c|c|c|c|c|c|c|c|c|c|}
\hline RCCPDX ID & AMEL & D10S1248 & D12S391 & D19S433 & D1S1656 & D22S1045 & D2S1338 & D2S441 & D6S1043 & TH01 \\
\hline RCCPDX22 /P4 & $X, Y$ & $14 ; 15$ & 16,$3 ; 17,3$ & $13 ; 15$ & 16,$3 ; 17,3 ; 18,3$ & 15,16 & $17 ; 21$ & $13 ; 14$ & 12 & $7 ; 9,3$ \\
\hline RCCPDX23 /P0 & $\mathrm{X} ; \mathrm{Y}$ & $14 ; 16$ & $18 ; 21$ & $13 ; 14$ & $14 ; 16$ & $16 ; 18$ & 19,$3 ; 25$ & $10 ; 14$ & $11 ; 13$ & 9,3 \\
\hline RCCPDX23 /P1 & $\mathrm{X} ; \mathrm{Y}$ & $14 ; 16$ & 18 & $13 ; 14$ & $14 ; 16$ & 16 & 19,$3 ; 25$ & $10 ; 14$ & $11 ; 13$ & 9,3 \\
\hline RCCPDX23 /P4 & $\mathrm{X}$ & $14 ; 16$ & 18 & $13 ; 14$ & $14 ; 16$ & 16 & 19,$3 ; 25$ & $10 ; 14$ & $11 ; 13$ & 9,3 \\
\hline RCCPDX24 /P0 & $\mathrm{X}$ & 14 & $18 ; 20$ & $14 ; 15$ & $12 ; 17$ & 16 & $17 ; 24$ & 14 & $13 ; 14$ & $8 ; 9,3$ \\
\hline RCCPDX24/P1 & $\mathrm{X}$ & 14 & $18 ; 20$ & $14 ; 15$ & $12 ; 17$ & 16 & $17 ; 24$ & 14 & $13 ; 14$ & $8 ; 9,3$ \\
\hline RCCPDX24 /P4 & $\mathrm{X}$ & 14 & $18 ; 20$ & $14 ; 15$ & $12 ; 17$ & 16 & $17 ; 24$ & 14 & $13 ; 14$ & $8 ; 9,3$ \\
\hline RCCPDX25 /P0 & $\mathrm{X}$ & $12 ; 14$ & $21 ; 22$ & $13 ; 15$ & $12 ; 16$ & $11 ; 14,3$ & $19 ; 20$ & 11 & 11 & $9 ; 9,3$ \\
\hline RCCPDX25/P1 & $\mathrm{X}$ & 14 & $21 ; 22$ & $13 ; 15$ & 16 & 15 & 19 & 11 & 11 & 9 \\
\hline RCCPDX25/P4 & $\mathrm{X}$ & $12 ; 14$ & $21 ; 22$ & $13 ; 15$ & 16 & 15 & 19 & 11 & 11 & 9 \\
\hline RCCPDX26/P0 & $X, Y$ & $14 ; 16$ & $18 ; 21$ & $13 ; 14$ & $14 ; 18,3$ & $13 ; 15$ & $17 ; 25$ & $11 ; 14$ & $12 ; 19$ & $9 ; 9,3$ \\
\hline RCCPDX26/P1 & $\mathrm{X}, \mathrm{Y}$ & $14 ; 16$ & & 13 & & $13 ; 15$ & $17 ; 25$ & $11 ; 14$ & 12 & \\
\hline RCCPDX26/P4 & $\mathrm{X}, \mathrm{Y}$ & $14 ; 16$ & $18 ; 21$ & 13 & $14 ; 18,3$ & $13 ; 15$ & $17 ; 25$ & $11 ; 14$ & $12 ; 19$ & $9 ; 9,3$ \\
\hline RCCPDX27 /P0 & $X, Y$ & $13 ; 16$ & $15 ; 22$ & $13 ; 15$ & $14 ; 15$ & $16 ; 17$ & $17 ; 22$ & $10 ; 11$ & $20 ; 22$ & $7 ; 9$ \\
\hline RCCPDX27 /P1 & $\mathrm{X}, \mathrm{Y}$ & 13. 16 & $15 ; 22$ & $13 ; 15$ & $14 ; 15$ & 16 & $17 ; 22$ & $10 ; 11$ & $20 ; 22$ & $7 ; 9$ \\
\hline RCCPDX27 /P4 & $\mathrm{X}, \mathrm{Y}$ & 13. 16 & $15 ; 22$ & $13 ; 15$ & $14 ; 15$ & 16 & $17 ; 22$ & $10 ; 11$ & $20 ; 22$ & $7 ; 9$ \\
\hline RCCPDX28 /P0 & $\mathrm{X}$ & $13 ; 14$ & $17 ; 24$ & 15 & $16 ; 16,3$ & 16 & $17 ; 23$ & $11 ; 14$ & $8 ; 11$ & $9 ; 10$ \\
\hline RCCPDX28 /P1 & $\mathrm{X}$ & $13 ; 14 ; 15$ & $17 ; 24$ & 15 & $16 ; 16,3$ & 16 & $17 ; 23$ & $11 ; 14$ & 11 & 10 \\
\hline RCCPDX28 /P3 & $\mathrm{X}$ & $13 ; 15$ & $17 ; 24$ & 15 & $16 ; 16,3$ & 16 & $17 ; 23$ & $11 ; 14$ & $8 ; 11$ & $9 ; 10$ \\
\hline RCCPDX29 /P0 & $\mathrm{X} ; \mathrm{Y}$ & $14 ; 15$ & 17 & $14 ; 15,2$ & $11 ; 12$ & $11 ; 14$ & $17 ; 19$ & $10 ; 11$ & $12 ; 18$ & $8 ; 9,3$ \\
\hline RCCPDX29 /P1 & $X ; Y$ & $14 ; 15$ & 17 & $14 ; 15,2$ & $11 ; 12$ & $11 ; 14$ & $17 ; 19$ & $10 ; 11$ & $12 ; 18$ & $8 ; 9,3$ \\
\hline RCCPDX29 /P3 & $\mathrm{X} ; \mathrm{Y}$ & $14 ; 15$ & 17 & $14 ; 15,2$ & $11 ; 12$ & $11 ; 14$ & $17 ; 19$ & $10 ; 11$ & $12 ; 18$ & $8 ; 9,3$ \\
\hline RCCPDX30 /P0 & $\mathrm{X} ; \mathrm{Y}$ & $12 ; 15$ & $18 ; 21$ & $13 ; 14$ & $13 ; 14 ; 16,3$ & $11 ; 16$ & $15 ; 16$ & $11 ; 13$ & $14 ; 20$ & 6 \\
\hline RCCPDX30 /P1 & $\mathrm{X} ; \mathrm{Y}$ & $12 ; 15$ & $18 ; 19 ; 21$ & $12 ; 14$ & $13 ; 15,3 ; 16,3$ & $11 ; 16$ & 15 & $12 ; 13$ & $15 ; 21$ & 6 \\
\hline RCCPDX30 /P4 & $\mathrm{X} ; \mathrm{Y}$ & $12 ; 14 ; 15$ & $18 ; 21$ & $12 ; 13 ; 14$ & $13 ; 15,3 ; 16,3$ & $11 ; 16$ & $15 ; 16$ & $11 ; 13$ & $15 ; 21$ & 6 \\
\hline
\end{tabular}

date of establishment during the last 30 years. However, each of these panels is useful and of great importance for translational research in the RCC field.

In conclusion, we have developed realistic preclinical models of RCC that will greatly accelerate the development of new therapeutic compounds and the elucidation of response and resistance mechanisms to current therapeutics. These models are difficult to develop, although sarcomatoid components of the tumors seem to greatly enhance the take rate, a feature that could not be specified when dealing with low numbers of PDX models. To our knowledge, our study constitutes one of the largest panel of preclinical PDX models for RCC. This panel will be useful for both patient prognosis and drug response since they recapitulate parental tumors histologically, genetically and molecularly. We can thus generate precise and reliable data, directly available for clinical applications, and this constitutes the first step to personalized medicine. 
Table 6: Von Hippel-Lindau gene sequencing (VHL sequence accession number: NG_008212.3)

\begin{tabular}{|c|c|c|c|}
\hline RCCPDX ID & Exon 1 & Exon2 & Exon3 \\
\hline RCCPDX13/P0 & - & 9945 dupT & - \\
\hline RCCPDX13/1 & - & 9945 dup T & - \\
\hline RCCPDX13/2 & - & 9945 dupT & - \\
\hline RCCPDX13/4 & - & 9945 dupT & - \\
\hline RCCPDX13/6 & - & 9945 dupT & - \\
\hline RCCPDX15/P0 & Del 5469-5474;Del 5477-5494 & - & - \\
\hline RCCPDX15/1 & Del 5469-5474;Del 5477-5494 & - & - \\
\hline RCCPDX $15 / 2$ & Del 5469-5474;Del 5477-5494 & - & - \\
\hline RCCPDX $15 / 4$ & Del 5469-5474;Del 5477-5494 & - & - \\
\hline RCCPDX16/P0 & - & - & Del 13238-13251 \\
\hline RCCPDX16/1 & - & - & Del 13238-13251 \\
\hline RCCPDX16/2 & - & - & Del 13238-13251 \\
\hline RCCPDX16/4 & - & - & Del 13238-13251 \\
\hline RCCPDX16/5 & - & - & Del 13238-13251 \\
\hline RCCPDX18/P0 & - & $9888 \mathrm{~T}>\mathrm{TA}$ & - \\
\hline RCCPDX18/1 & - & $9888 \mathrm{~T}>\mathrm{TA}$ & - \\
\hline RCCPDX18/2 & - & $9888 \mathrm{~T}>\mathrm{TA}$ & - \\
\hline RCCPDX18/4 & - & $9888 \mathrm{~T}>\mathrm{TA}$ & - \\
\hline RCCPDX18/6 & - & $9888 \mathrm{~T}>\mathrm{TA}$ & - \\
\hline RCCPDX18/8 & - & $9888 \mathrm{~T}>\mathrm{TA}$ & - \\
\hline RCCPDX23/P0 & - & - & - \\
\hline RCCPDX23/1 & - & - & - \\
\hline RCCPDX23/2 & - & - & - \\
\hline RCCPDX23/4 & - & - & - \\
\hline RCCPDX23/6 & - & - & - \\
\hline
\end{tabular}


RCCPDX1 (CCC)
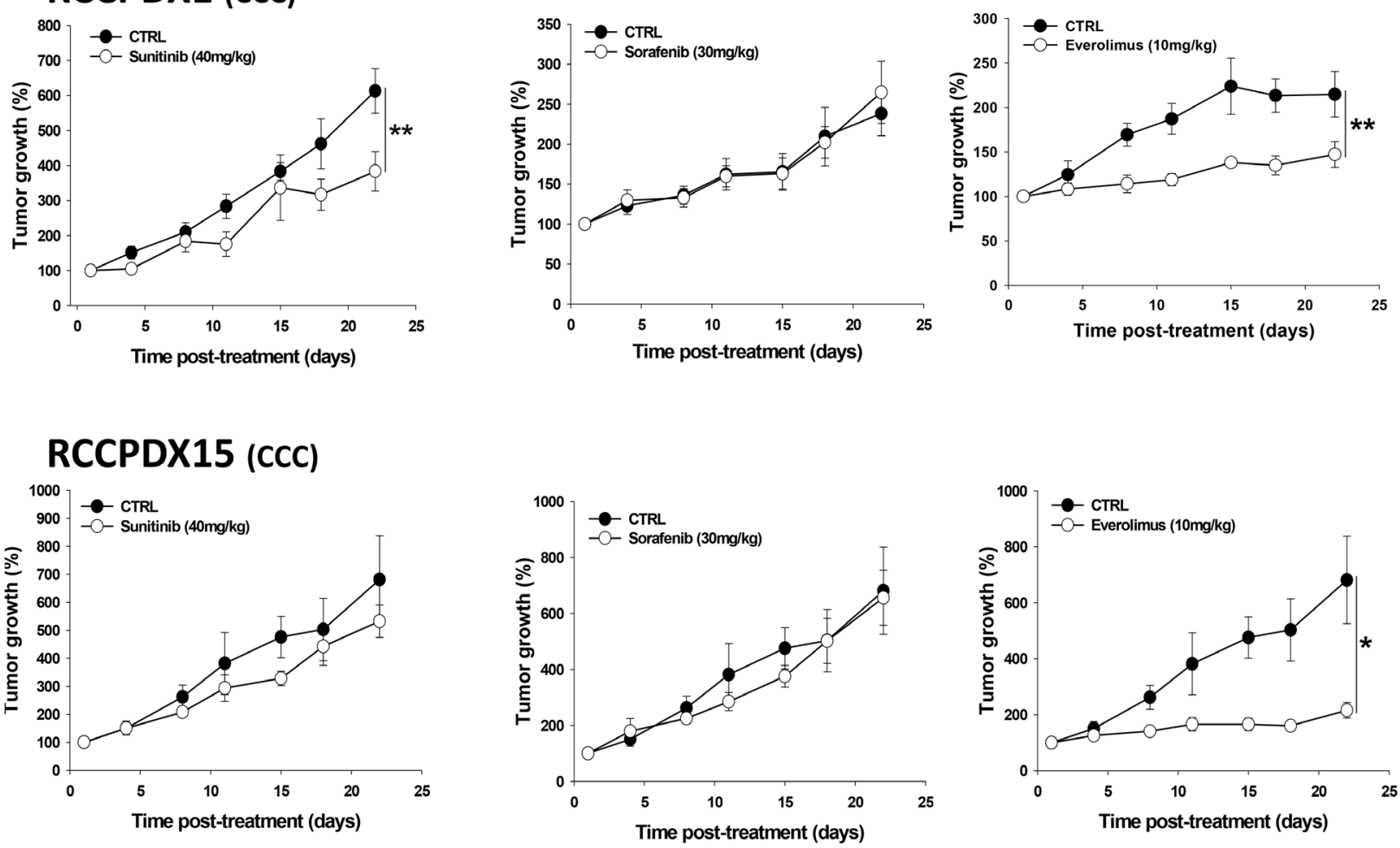

RCCPDX18 (CCC)
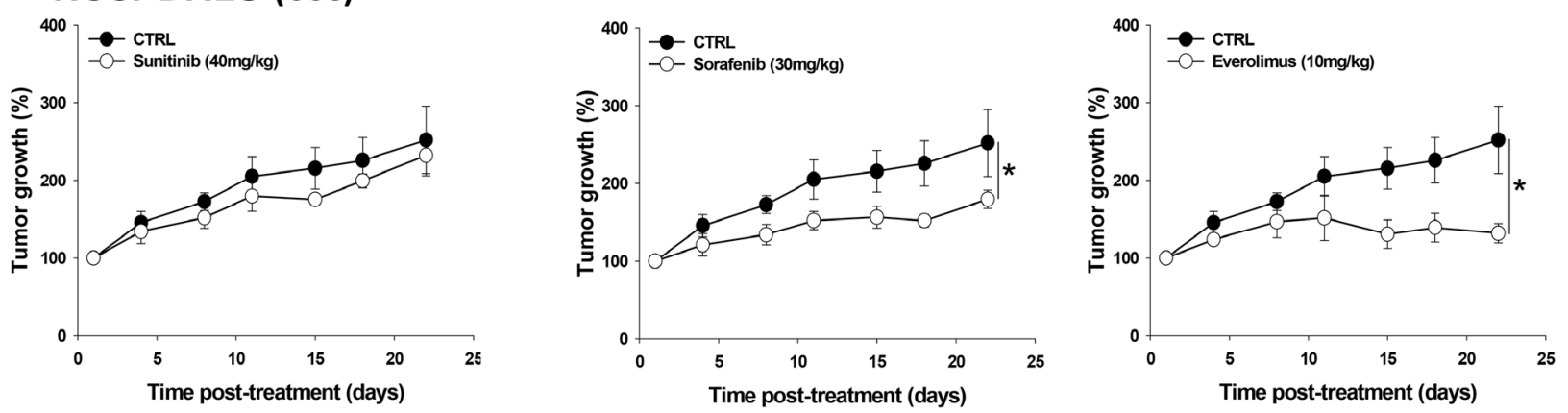

\section{RCCPDX30 (CCC)}
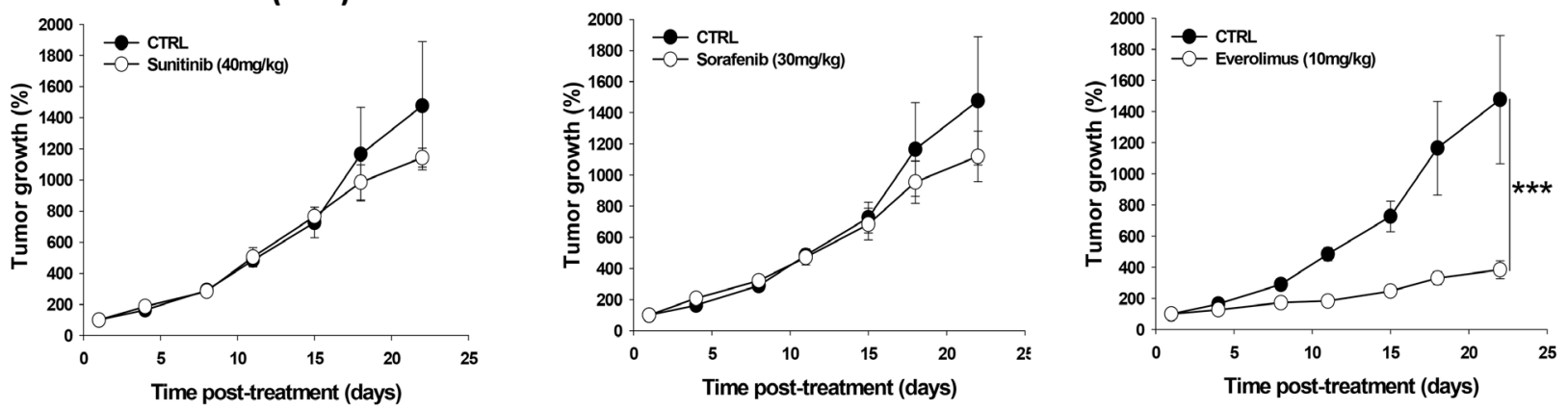

Figure 5: In vivo growth curves of 4 RCCPDX tumors of the CCC subtype treated with sunitinib, sorafenib or everolimus for the indicated time period. Results are expressed in \% from day 1 and as mean $+/-$ sem, $n=4$ to 5 for each curve. $*, \mathrm{P}<0.05$; **, $\mathrm{P}<0.01 ; * * *, \mathrm{P}<0.001$ comparing treated to control groups. Note: mice were divided into four groups, the control and the treated groups i.e. one group for each compounds tested, except for RCCPDX1 where mice were divided into two groups, the control and the treated group for each compound tested. 
Table 7: Additional patients' responses to targeted therapies

\begin{tabular}{lccc}
\hline RCCPDX ID & Sunitinib & Sorafenib & Everolimus \\
\hline RCCPDX3 & $\mathrm{NR}$ & $\mathrm{NR}$ & $\mathrm{R}^{*}$ \\
RCCPDX4 & $\mathrm{NR}$ & $\mathrm{R} *$ & $\mathrm{NR}$ \\
RCCPDX6 & $\mathrm{R} *$ & $\mathrm{R}^{* *}$ & $\mathrm{R} * *$ \\
RCCPDX10 & $\mathrm{NR} / \mathrm{PP}$ & $\mathrm{ND}$ & $\mathrm{ND}$ \\
\hline
\end{tabular}

* $\mathrm{P}<0.05 ; * * \mathrm{P}<0.01$ from control. R: Responder. NR: Non responder. PP: Predictive of the patient's therapeutic response. ND: not determined.
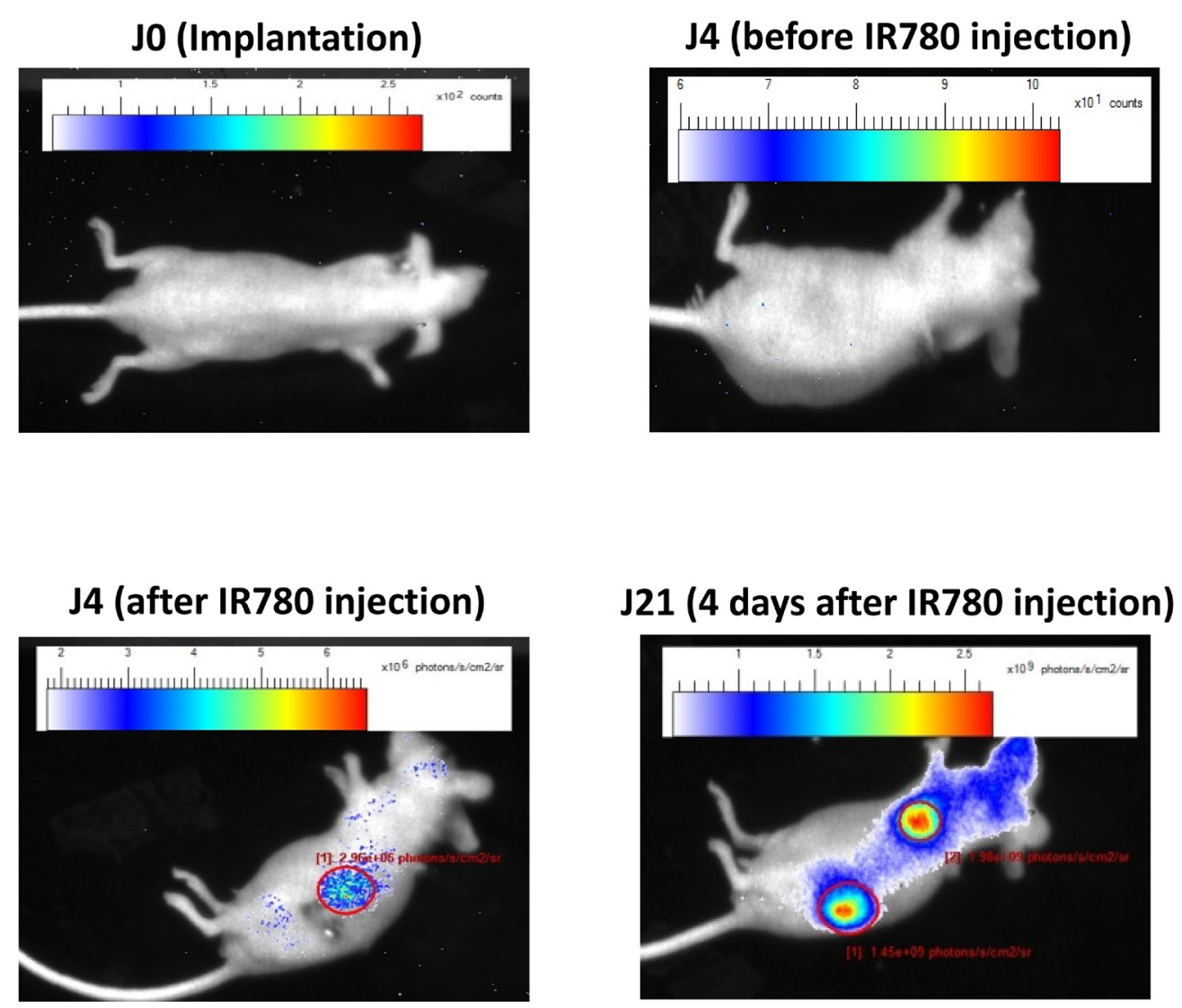

\section{J24 (7 days after IR780 injection)}
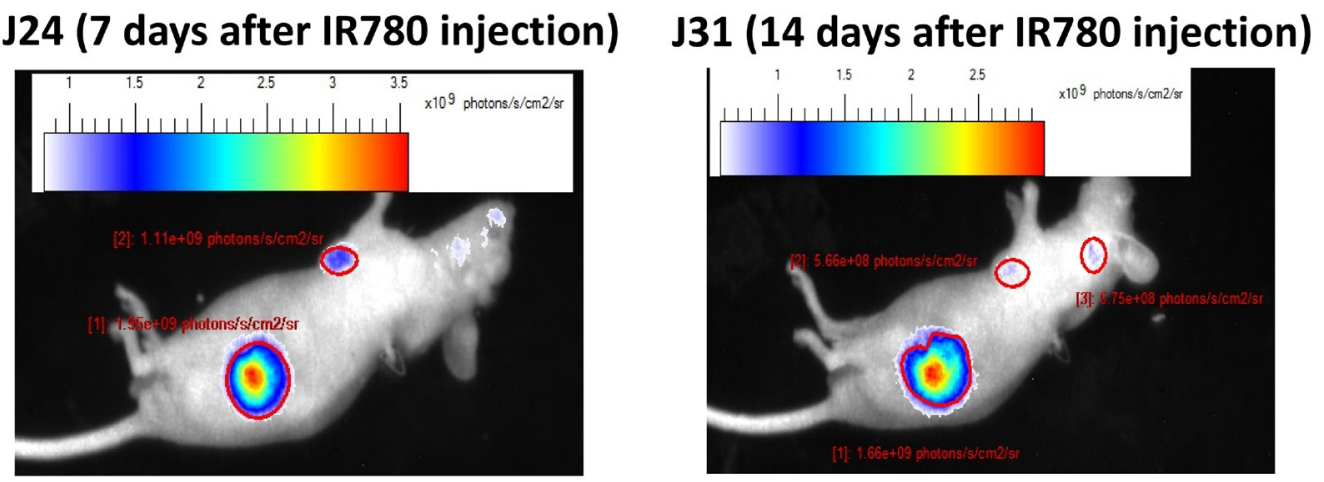

Figure 6: Metastasis analysis in an orthotopic model. In vivo infrared imaging in RCCPDX20 after orthotopic implantation at different days before and after iv injection of the IR780 dye, showing primary tumors and metastasis development. 


\section{MATERIALS AND METHODS}

\section{Animals}

4-week old male $\mathrm{Nu} / \mathrm{Nu}$ athymic mice were purchased from Charles River (L'Arbresle, France). Mice were housed in ventilated carousel racks and provided with sterile food and drink water. All the mouse experiments reported herein were approved by Animal Housing and Experiment Board of the French government.

\section{Patients and tumor processing and grafting}

Fresh samples were obtained from 336 human RCC tumors between 2007 and 2014 (Table 1 and Table 2). All patients provided written informed consent. Patient material was de-identified according to clinical processes and French law regulations for patient information and consent. After surgery, tissue specimens were immediately transferred on ice in DMEM medium additioned with penicillin/ streptomycine to the animal facility. Tumors were dissected, washed in DMEM medium, cut into $5 \mathrm{~mm}^{3}$ pieces and grafted subcutaneously in 5 mice under general isoflurane gaseous anaesthesia. All this procedure was performed in sterile conditions and in less than 30 min post-surgery. For each tumor, some pieces of tissue were snap-frozen in liquid nitrogen for genetic and molecular characterization, others formalin-fixed for histological or immunohistological analysis and the rest keep frozen in FBS/DMSO mixture $(90 / 10 \%)$ used for new passages (P) in mice. In addition, pieces of corresponding normal tissues harvested at the edge of the tumors at the time of surgery were snap-frozen in liquid nitrogen and others formalin-fixed for tumor/normal tissues comparison studies. The study was conducted in accordance with the Declaration of Helsinski.

\section{Tumor passaging and storage}

Once the grafted tumors reached $500-1000 \mathrm{~mm}^{3}$, mice were subjected to general anaesthesia provided as stated in the appendix and tumors were dissected under sterile conditions. Tumors were then cut into small pieces of $5 \mathrm{~mm}^{3}$ and washed in PBS. Again, as stated in the appendix for the primary tumors (P0), the pieces were divided into 4 parts, one of them used for the subsequent passages. To date, the tumors that developed in mice have been serially passages up to 13 passages (P13).

\section{Orthotopic tumor implantation}

Mice were placed on the right lateral side under general anaesthesia as stated above. A skin incision was made in the left flank to localize the left kidney. The renal capsule was then incised and a small piece of tumor obtained from subcutaneous implantation was then placed under the capsule. The abdominal wall was then closed with suture.

\section{Histology}

For all RCCPDX models, primary and passaged tumors preserved in formalin were paraffin-embedded and process into $5 \mu \mathrm{m}$ thick cuts and placed on glass slides. Hematoxylin and eosin (H\&E) staining and slides analysis were performed by an experienced uropathologist.

\section{Transcriptome analysis}

Total RNA from patients' primary tumors and from corresponding tumors at passage ranging from P1 to P8 was obtained using Qiagen columns according to manufacturer's protocol. The concentration and integrity/purity of each RNA sample were measured using RNA 6000 LabChip kit (Agilent) and the Agilent 2100 bioanalyzer. U133 Plus 2.0 array containing 54,624 probe sets excluding the AFFY quality control probe sets representing 20313 human genes (Affymetrix, Santa Clara, CA, USA). The Transcriptome analysis was performed by Firalis SAS (Huningue, France), a biotech specialized in biomarkers identification on $100 \mathrm{ng}$ of total RNA that were amplified and labeled according to the Affymetrix protocol. The RMA data were reported as log2-transformed intensities. Descriptive statistics antilog intensities across all tumors were used. Prefiltering excluded all probe sets with Affy QC. The expression values for each individual passaged tumors was normalized separately on primary tumor expression values. $\log 2$ transformation of fold changes (FC) was used. In order to check the quality of the individual microarrays the intensity distribution of all samples were calculated and compared. Exploration analysis included principal component analysis, hierarchical clustering and heatmap visualization.

\section{Short tandem repeat analysis}

DNA from patients' primary tumors and from corresponding tumors at passage ranging from $\mathrm{P} 1$ to $\mathrm{P} 4$ was obtained by phenol/chloroform extraction A nanodrop ND-1000 spectrophotometer (Thermo scientific, Illkirch, France) was used to determine DNA concentration and purity. DNA samples were subjected to short tandem repeat (STR) DNA fingerprinting using the AuthentiFiler PCR amplification Kit (Life technologies, Saint Aubin, France) that amplifies 9 unique STR loci (8 that comprise tetranucleotide repeat units and one locus trinucleotide) and the Amelogenin gender-determining marker, according to manufacturer instructions. PCR products were separated by capillary electrophoresis on a genetic analyzer ABI PRISM 3100 and results analyzed using the GeneMapper software.

\section{Von Hippel-Lindau gene sequencing}

The 3 exons encoding the VHL gene were amplified by polymerase chain reaction (PCR) using specific primers 
pairs The high fidelity KAPA Taq DNA polymerase (Clinisciences, Nanterre, France) was used and PCR products were purified using nucleospin PCR cleanup columns (Macherey-Nagel, Hoerdt, France). Both directions sequencing as well as sequence alignment and comparison to the reference sequence was performed by Millegen (Labège, France), and GATC biotech (Cologne, Germany).

\section{Treatment with reference compounds}

For each serie, once tumor volume reached a palpable size (around $100 \mathrm{~mm}^{3}$ ), mice were randomly divided into different groups, control (diluent) and treated groups, as indicated in the corresponding Figure legend. Mice were treated per os with diluent (cremophor 10\%, DMSO 5\% in PBS) or sunitinib, sorafenib or everolimus (Euromedex, Souffelweyersheim, France). Sunitinib (40 mg/kg) was administered 3 times/week for 3 weeks. Sorafenib $(30 \mathrm{mg} / \mathrm{kg})$ and everolimus $(10 \mathrm{mg} / \mathrm{kg})$ were administered 5 times per week for 3 weeks. Tumor growth was measured using a caliper as previously detailed [10].

\section{Tumor and metastasis imagery}

To image tumors and metastasis we used the Heptamethine cyanine dye IR-780 iodide which accumulates in tumor cells [37]. IR-780 $0.2 \mathrm{mg} / \mathrm{kg}, 200$ $\mu \mathrm{l})$ was injected ip 24-48h before NIR imaging coupled to X-ray which was performed using a multimodality imaging system for small animal (Biospace photon imager, Institut Pluridisciplinaire Hubert Curien, Strasbourg).

\section{Statistical analysis}

All values are expressed as mean \pm s.e.m. Statistical analysis was performed when appropriate using Student's $t$ test, one-way or two-way ANOVA followed by the Student-Newman-Keul's test for multiple comparisons.

For cDNA arrays on Affymetrix, a 2 way ANOVA considering tissue and passage (P0 to $\mathrm{P} 8$ ) as factors and Post-Hoc tests (contrasts) for P0 vs P1, and P1 vs P2, P1 vs P4, P1 vs P5, P1 vs P6, and P1 vs P8, were used.

A $P<0.05$ was considered significant (BenjaminiHochberg).

\section{ACKNOWLEDGMENTS}

We thank the team of Pr Seiamak Bahram, Molecular Immuno Rhumatology, INSERM U1109, Strasbourg, France, for access to the ABI PRISM 3100 and the team of Dr David Brasse, Institut Pluridisciplinaire Hubert Curien (IPHC), Imabio group, CNRS UMR 7178, Strasbourg Cronenbourg, France, for small animal imagery. We also thank the competitivity pole Alsace Biovalley, Illkirch-Graffenstaden, France for advices and labelization. Finally, we also thank Alsace Satt Conectus, Illkirch-Graffenstaden, France, for technologies transfer and advices.

\section{CONFLICTS OF INTEREST}

The authors declare no conflict of interests.

\section{GRANT SUPPORT}

We thank BPI France, the Region Alsace, the European Funds for Regional Development, the Strasbourg Urban Community, INSERM and the University of Strasbourg for financial supports. We also thank the Alsace incubator SEMIA, Strasbourg, France, for financial supports and advices.

\section{REFERENCES}

1. Ferlay J, Soerjomataram I, Dikshit R, Eser S, Mathers C, Rebelo M, Parkin DM, Forman D, Bray F. Cancer incidence and mortality worldwide: sources, methods and major patterns in GLOBOCAN 2012. Int J Cancer. 2015; 136:E359-386.

2. Escudier B, Porta C, Bono P, Powles T, Eisen T, Sternberg CN, Gschwend JE, De Giorgi U, Parikh O, Hawkins R, Sevin E, Négrier S, Khan S, et al. Randomized, controlled, double-blind, cross-over trial assessing treatment preference for pazopanib versus sunitinib in patients with metastatic renal cell carcinoma: PISCES Study. J Clin Oncol. 2014; 32:1412-1418

3. Eker R. Familial renal adenomas in Wistar rats; a preliminary report. Acta Pathol Microbiol Scand. 1954; 34:554-562.

4. Yeung RS, Xiao GH, Jin F, Lee WC, Testa JR, Knudson AG. Predisposition to renal carcinoma in the Eker rat is determined by germ-line mutation of the tuberous sclerosis 2 (TSC2) gene. Proc Natl Acad Sci USA. 1994; 91:11413-11416.

5. Wolf DC, Whiteley HE, Everitt JI. Preneoplastic and neoplastic lesions of rat hereditary renal cell tumors express markers of proximal and distal nephron. Vet Pathol. 1995; 32:379-386.

6. Kleymenova E, Everitt JI, Pluta L, Portis M, Gnarra JR, Walker CL. Susceptibility to vascular neoplasms but no increased susceptibility to renal carcinogenesis in Vhl knockout mice. Carcinogenesis. 2004; 25:309-315.

7. Fu L, Wang G, Shevchuk MM, Nanus DM, Gudas LJ. Generation of a mouse model of Von Hippel-Lindau kidney disease leading to renal cancers by expression of a constitutively active mutant of HIF1 $\alpha$. Cancer Res. 2011; 71:6848-6856.

8. Dressler GR, Wilkinson JE, Rothenpieler UW, Patterson LT, Williams-Simons L, Westphal H. Deregulation of Pax-2 
expression in transgenic mice generates severe kidney abnormalities. Nature. 1993; 362:65-67.

9. Wang H, Zhang P, Lin C, Yu Q, Wu J, Wang L, Cui Y, Wang K, Gao Z, Li H. Relevance and therapeutic possibility of PTEN-long in renal cell carcinoma. PLoS One. 2015; 10:e114250.

10. Dormoy V, Béraud C, Lindner V, Coquard C, Barthelmebs M, Brasse D, Jacqmin D, Lang H, Massfelder T. Vitamin D3 triggers antitumor activity through targeting hedgehog signaling in human renal cell carcinoma. Carcinogenesis. 2012; 33:2084-2093.

11. Iliopoulos O, Kibel A, Gray S, Kaelin WG Jr. Tumour suppression by the human von Hippel-Lindau gene product. Nat Med. 1995; 1:822-826.

12. Reinecke P, Schmitz M, Schneider EM, Gabbert HE, Gerharz CD. Multidrug resistance phenotype and paclitaxel (Taxol) sensitivity in human renal carcinoma cell lines of different histologic types. Cancer Invest. 2000; 18:614-625.

13. Reinecke $\mathrm{P}$, Corvin J, Gabbert HE, Gerharz CD. Antiproliferative effects of paclitaxel (Taxol) on human renal clear cell carcinomas in vitro. Eur J Cancer. 1997; 33:1122-1129.

14. Kurth KH, Romijn JC, Kappendijk M, Weissglas MG, van Dongen JW. In vivo and in vitro chemotherapy sensitivity testing for human kidney tumor lines: a comparative study. Semin Surg Oncol. 1988; 4:103-109.

15. Bernardo C, Costa C, Sousa N, Amado F, Santos L. Patientderived bladder cancer xenografts: a systematic review. Transl Res. 2015; [Epub ahead of print].

16. DeRose YS, Wang G, Lin YC, Bernard PS, Buys SS, Ebbert MT, Factor R, Matsen C, Milash BA, Nelson E, Neumayer L, Randall RL, Stijleman IJ, et al. Tumor grafts derived from women with breast cancer authentically reflect tumor pathology, growth, metastasis and disease outcomes. Nat Med. 2011; 17:1514-1520.

17. Mattie M, Christensen A, Chang MS, Yeh W, Said S, Shostak Y, Capo L, Verlinsky A, An Z, Joseph I, Zhang Y, Kumar-Ganesan S, Morrison K, et al. Molecular characterization of patient-derived human pancreatic tumor xenograft models for preclinical and translational development of cancer therapeutics. Neoplasia. 2013; 15:1138-1150.

18. Ilie M, Nunes M, Blot L, Hofman V, Long-Mira E, Butori C, Selva E, Merino-Trigo A, Vénissac N, Mouroux J, Vrignaud P, Hofman P. Setting up a wide panel of patientderived tumor xenografts of non-small cell lung cancer by improving the preanalytical steps. Cancer Med. 2015; 4:201-211

19. Hasan N, Ohman AW, Dinulescu DM. The promise and challenge of ovarian cancer models. Transl Cancer Res. 2015; 4:14-28.

20. Gupta J, Igea A, Papaioannou M, Lopez-Casas PP, Llonch E, Hidalgo M, Gorgoulis VG, Nebreda AR. Pharmacological inhibition of p38 MAPK reduces tumor growth in patient-derived xenografts from colon tumors. Oncotarget. 2015; 6:8539-8351. doi: 10.18632/ oncotarget.3816.

21. Hu H, Qiu Y, Guo M, Huang Y, Fang L, Peng Z, Ji W, Xu Y, Shen S, Yan Y, Huang X, Zheng J, Su C. Targeted Hsp70 expression combined with CIK-activated immune reconstruction synergistically exerts antitumor efficacy in patient-derived hepatocellular carcinoma xenograft mouse models. Oncotarget. 2015; 6:1079-1089. doi: 10.18632/ oncotarget. 2835.

22. Némati F, Sastre-Garau X, Laurent C, Couturier J, Mariani P, Desjardins L, Piperno-Neumann S, Lantz O, Asselain B, Plancher C, Robert D, Péguillet I, Donnadieu MH, et al. Establishment and characterization of a panel of human uveal melanoma xenografts derived from primary and/or metastatic tumors. Clin Cancer Res. 2010; 16:2352-2362.

23. Jiménez-Valerio G, Martínez-Lozano M, Bassani N, Vidal A, Ochoa-de-Olza M, Suárez C, García-Del-Muro X, Carles J, Viñals F, Graupera M, Indraccolo S, Casanovas O. Resistance to Antiangiogenic Therapies by Metabolic Symbiosis in Renal Cell Carcinoma PDX Models and Patients. Cell Rep. 2016; 15:1134-1143.

24. Schuller AG, Barry ER, Jones RD, Henry RE, Frigault MM, Beran G, Linsenmayer D, Hattersley M, Smith A, Wilson J, Cairo S, Déas O, Nicolle D, et al. The MET Inhibitor AZD6094 (Savolitinib, HMPL-504). Induces Regression in Papillary Renal Cell Carcinoma Patient-Derived Xenograft Models. Clin Cancer Res. 2015; 21:2811-2819.

25. Adelaiye R, Ciamporcero E, Miles KM, Sotomayor P, Bard J, Tsompana M, Conroy D, Shen L, Ramakrishnan S, Ku SY, Orillion A, Prey J, Fetterly G, Buck M, Chintala S, Bjarnason GA, Pili R. Sunitinib dose escalation overcomes transient resistance in clear cell renal cell carcinoma and is associated with epigenetic modifications. Mol Cancer Ther. 2015; 14:513-522.

26. Bieche I, Vacher S, Vallerand D, Richon S, Hatem R, De Plater L, Dahmani A, Némati F, Angevin E, Marangoni E, Roman-Roman S, Decaudin D, Dangles-Marie V. Vasculature analysis of patient derived tumor xenografts using species-specific PCR assays: evidence of tumor endothelial cells and atypical VEGFA-VEGFR1/2 signalings. BMC Cancer. 2014; 14:178.

27. Thong AE, Zhao H, Ingels A, Valta MP, Nolley R, Santos J, Young SR, Peehl DM. Tissue slice grafts of human renal cell carcinoma: an authentic preclinical model with high engraftment rate and metastatic potential. Urol Oncol. 2014; 32:43.e23-30.

28. Sivanand S, Peña-Llopis S, Zhao H, Kucejova B, Spence P, Pavia-Jimenez A, Yamasaki T, McBride DJ, Gillen J, Wolff NC, Morlock L, Lotan Y, Raj GV, et al. A validated tumorgraft model reveals activity of dovitinib against renal cell carcinoma. Sci Trans1 Med. 2012; 4:137ra75.

29. Karam JA, Zhang XY, Tamboli P, Margulis V, Wang H, Abel EJ, Culp SH, Wood CG. Development and characterization 
of clinically relevant tumor models from patients with renal cell carcinoma. Eur Urol. 2011; 59:619-628.

30. Angevin E, Glukhova L, Pavon C, Chassevent A, TerrierLacombe MJ, Goguel AF, Bougaran J, Ardouin P, Court BH, Perrin JL, Vallancien G, Triebel F, Escudier B. Human renal cell carcinoma xenografts in SCID mice: tumorigenicity correlates with a poor clinical prognosis. Lab Invest. 1999; 79:879-888.

31. Glukhova L, Goguel AF, Chudoba I, Angevin E, Pavon C, Terrier-Lacombe MJ, Meddeb M, Escudier B, Bernheim A. Overrepresentation of $7 \mathrm{q} 31$ and $17 \mathrm{q}$ in renal cell carcinomas. Genes Chromosomes Cancer. 1998; 22:171-178.

32. Knöfel WT, Otto U, Baisch H, Klöppel G. Stability of human renal cell carcinomas during long term serial transplantation into nude mice: histopathology, nuclear grade, mitotic rate, and DNA content in thirty tumors. Cancer Res. 1987; 47:221-224.

33. Baisch H, Otto U, Klöppel G. Long-term serial transplantation of 30 different human renal cell carcinomas into NMRI (nu/nu) mice: flow cytometric, histologic, and growth studies. J Natl Cancer Inst. 1986; 76:269-276.

34. Katsuoka Y, Baba S, Hata M, Tazaki H. Transplantation of human renal cell carcinoma to the nude mice: as an intermediate of in vivo and in vitro studies. J Urol. 1976; 115:373-6.

35. Santos FR, Pandya A, Tyler-Smith C. Reliability of DNAbased sex tests. Nat Genet. 1998; 18:103.

36. Park B, Jeong BC, Choi YL, Kwon GY, Lim JE, Seo SI, Jeon SS, Lee HM, Choi HY, Lee KS. Development and characterization of a bladder cancer xenograft model using patient-derived tumor tissue. Cancer Sci. 2013; 104:631-638.

37. Wang Y, Liu T, Zhang E, Luo S, Tan X, Shi C. Preferential accumulation of the near infrared heptamethine dye IR-780 in the mitochondria of drug-resistant lung cancer cells. Biomaterials. 2014; 35:4116-4124. 